\title{
Seismic modelling of metre-scale normal faults at a reservoir-cap rock interface in Central Spitsbergen, Svalbard: implications for $\mathrm{CO}_{2}$ storage
}

\author{
Paul Lubrano-Lavadera' ${ }^{1}, K_{i m}$ Senger ${ }^{1}$, Isabelle Lecomte ${ }^{2,4}$, Mark Joseph Mulrooney ${ }^{1,3}$ \\ \& Daniela Kühn ${ }^{4,5}$
}

\author{
${ }^{1}$ Department of Arctic Geology, University Centre in Svalbard, PO Box 156, 9171 Longyearbyen, Norway. \\ ${ }^{2}$ Department of Earth Science, University of Bergen, Allégaten 41, 5007 Bergen, Norway. \\ ${ }^{3}$ Department of Geosciences, University of Oslo, PO Box 1047 Blindern, Oslo, Norway. \\ ${ }^{4}$ NORSAR, Gunnar Randers vei 15, 2007 Kjeller, Norway. \\ ${ }^{5}$ GFZ German Research Centre for Geosciences, Helmholtzstr. 6/7, 14467 Potsdam, Germany.
}

E-mail corresponding author (Kim Senger): kim.senger@unis.no

On Svalbard (Arctic Norway), a pilot-scale research project has been established to investigate the feasibility of storing locally produced $\mathrm{CO}_{2}$ in geological aquifers onshore. Drilling, geophysical and geological data acquisition and water-injection tests confirm the injectivity and storage capacity of the naturally fractured and compartmentalised siliciclastic storage unit that is located at c. $670-1000 \mathrm{~m}$ depth below the proposed injection site in Adventdalen, Central Spitsbergen. Excellent outcrops of the reservoir-caprock units $15 \mathrm{~km}$ from the planned injection site allow for detailed sedimentological and structural studies, and complement 2D seismic data acquired onshore and offshore. In this contribution, we focus on small-scale (metre-scale displacement) normal faults present in both reservoir and caprock to quantify their seismic detectability. We generate synthetic seismic sections of structural models based on high-resolution virtual outcrop models populated with elastic parameters from wireline log data. We address a number of geological scenarios, focusing on $\mathrm{CO}_{2}$ migration within the compartmentalised reservoir, its baffling by normal fault zones and migration of $\mathrm{CO}_{2}$ along a hypothetical fault in the caprock. Our results indicate that while the small-scale faults are unlikely to be imaged on conventional $2 \mathrm{D}$ seismic data, the fluid effect associated with $\mathrm{CO}_{2}$ migration along the fault zone will generate considerable reflectivity contrasts and should result in good definition of the extent of the $\mathrm{CO}_{2}$ plume even in such structurally confined settings.

Keywords: Imaging, Fault, Svalbard, Seismic, Virtual outcrop, $\mathrm{CO}_{2}$ monitoring

Received 30. January 2018 / Accepted 11. October 2018 / Published online 27. November 2019

\section{Introduction}

Large-scale sequestration of $\mathrm{CO}_{2}$ in geological aquifers is considered as a potential mid-term solution to ameliorate the global increase in anthropogenic $\mathrm{CO}_{2}$ emissions, but is only conducted at a limited number of sites worldwide, typically offshore (Bachu, 2008; Michael et al., 2010; Ringrose et al., 2017). Subsurface injection of $\mathrm{CO}_{2}$ has been utilised by the oil industry for over 50 years as part of enhanced oil recovery projects, and is particularly actively used onshore North America (Gozalpour et al., 2005). In Europe, $\mathrm{CO}_{2}$ is currently stored at two industrial-scale sites offshore Norway, Sleipner and Snøhvit, with approximately 1.5 million tonnes of cumulative injection annually (Eiken et al., 2011). Pilot-scale $\mathrm{CO}_{2}$ storage projects have been undertaken onshore, notably at the Ketzin site in Germany (Kempka \& Kühn, 2013; Bergmann et al., 2016), the Hontomin site in Spain (Vilamajó et al., 2013; Ogaya et al., 2013) and the Frio site onshore Texas, USA (Daley et al., 2008; Doughty et al., 2008). Such pilot-scale sites greatly contribute to understanding how $\mathrm{CO}_{2}$ migrates in a variety of 
geological reservoirs, how $\mathrm{CO}_{2}$ can be effectively monitored and how injection strategies can be optimised. Onshore Svalbard, such a pilot-study was initiated by the University Centre in Svalbard in 2007 (Braathen et al., 2012). Longyearbyen, Svalbard's main settlement, is well suited for this endeavour due to 1 ) proximity to a $\mathrm{CO}_{2}$ point source, the coal-fuelled power plant, 2) favourable geological conditions with a reservoir-cap rock system below Longyearbyen and 3) local infrastructure and competence in high Arctic technical operations under strict environmental laws.

The injection of fluids into the subsurface raises the risk of seal failure and fluid migration along pre-existing zones of weakness (e.g., faults, fracture corridors; Ogata et al., 2014a). Understanding the detection thresholds of such events requires careful modelling of the relevant imaging techniques (e.g., seismic, EM, gravity). Such models are rarely based on outcrop-based geological models where forward modelling may serve as an important link to quantify the effects of fluid migration within the reservoir and caprock on the expected seismic image. This bridging between outcrop and seismic data is vital for improved seismic interpretation and the evaluation of sub-seismic features with significant potential to impact fluid flow, as e.g., the fault zones identified in central Spitsbergen. Seismic modelling also allows testing of different scenarios which are paramount both in the context of hydrocarbon exploration and $\mathrm{CO}_{2}$ sequestration.

Lubrano-Lavadera et al. (2018) presented a large-scale synthetic study of seismic imaging of a $\mathrm{CO}_{2}$ plume, partly based on the regional, dipping, Longyearbyen $\mathrm{CO}_{2}$ lab reservoir geometry (Figs. $1 \& 2$ ). Nonetheless, no dedicated studies have so far addressed the outcropping section of the Longyearbyen $\mathrm{CO}_{2}$ lab target, despite the availability of excellent exposures of small-scale fluidflow barriers such as faults and igneous intrusions (Senger et al., 2013; Ogata et al., 2014b). In addition, there is a clear need to quantify how fault imaging will be affected by the presence of fluids such as migration of $\mathrm{CO}_{2}$ through a fault in the caprock:

- In a specific range of geological parameters and elastic properties representative for the Longyearbyen $\mathrm{CO}_{2}$ lab, what is the seismic detectability if $\mathrm{CO}_{2}$ starts propagating along a fault zone in the caprock?

- Can seismic surveys constrain the edge of a $\mathrm{CO}_{2}$ volume in a segmented reservoir?

In this contribution, we demonstrate a complete workflow of generating synthetic seismic images of virtual outcrop models. We focus on outcrops in central Spitsbergen exhibiting small-scale normal faults affecting the $\mathrm{CO}_{2}$ storage reservoir and caprock. We extract the main geometrical features from the outcrops to construct a realistic geometrical model. We use well data to populate it with representative elastic parameters. Subsequently, we test a $\mathrm{CO}_{2}$ leakage scenario to determine the detectability of a potential $\mathrm{CO}_{2}$ migration along a fault system propagating into the caprock shales.

\section{Project overview and geological setting}

The Longyearbyen $\mathrm{CO}_{2}$ lab project aims to inject $\mathrm{CO}_{2}$ into the subsurface in central Spitsbergen in order to 1 ) reduce local atmospheric $\mathrm{CO}_{2}$ emissions from the coalfuelled power plant (c. 70,000 tons of $\mathrm{CO}_{2}$ per annum), 2) improve the understanding of monitoring $\mathrm{CO}_{2}$ flow in the subsurface, and 3) optimise injection strategies of $\mathrm{CO}_{2}$ into unconventional reservoirs. The latter two points are directly applicable to larger-scale $\mathrm{CO}_{2}$ storage projects offshore, where prohibitive costs hamper such feasibility studies. Braathen et al. (2012) provided a comprehensive overview of the Longyearbyen $\mathrm{CO}_{2}$ lab project's motivation and initial phase. Senger et al. (2015) presented initial storage capacity estimates and highlight some of the geological uncertainties present. The project's Phase II final report (Unis $\mathrm{CO}_{2} \mathrm{Lab}$ AS, 2015) summarises all subsurface work including the discovery of natural gas and the subsequent need for comprehensive plugging and abandonment of the boreholes.

2D seismic data illustrate the SW regional dip of the reservoir-caprock system (Bælum et al., 2012). The targeted reservoir is a naturally fractured siliciclastic unit comprising sandstones, conglomerates and siltstones with intraformational shale units, and belongs to the Upper Triassic to Middle Jurassic Kapp Toscana Group (Fig. 1; Braathen et al., 2012). The Kapp Toscana Group reservoir comprises a relatively thin (15-24 m) upper reservoir, the Norian-Aalenian Wilhelmøya Subgroup (Rismyhr et al., 2019), and a thicker (c. $270 \mathrm{~m}$ ) lower reservoir, the Carnian-early Norian De Geerdalen Formation (Fig. 2). The matrix porosity is somewhat better in the upper reservoir (6-20\%) compared to the lower reservoir (2-16\%; Mørk, 2013; Senger et al., 2015). The reservoir is heavily fractured, and natural fractures have been characterised in detail in both drillcores and outcrop exposures (Ogata et al., 2012, 2014b). Natural fractures contribute to improved permeability, fluid access to secondary, dissolution-related, porosity, and are estimated to contribute with $2.5 \%$ of storage potential (Senger et al., 2015). The shale-dominated caprock belongs to the Bathonian-Ryazanian Agardhfjellet Formation (Koevoets et al., 2019), the time-equivalent of the prolific Late Jurassic source rocks of the Norwegian Continental Shelf. As part of the research effort, waterinjection tests were conducted to quantify the reservoir injectivity. Approximately $1500 \mathrm{~m}^{3}$ of water were injected through the DH7A borehole in September 2012, at an approximately stable rate of around $460 \mathrm{~m}^{3} /$ day (Larsen, 2012; Senger et al., 2015). These injection tests confirm good injectivity and a flow capacity of $39 \mathrm{mD} \cdot \mathrm{m}$, but also 


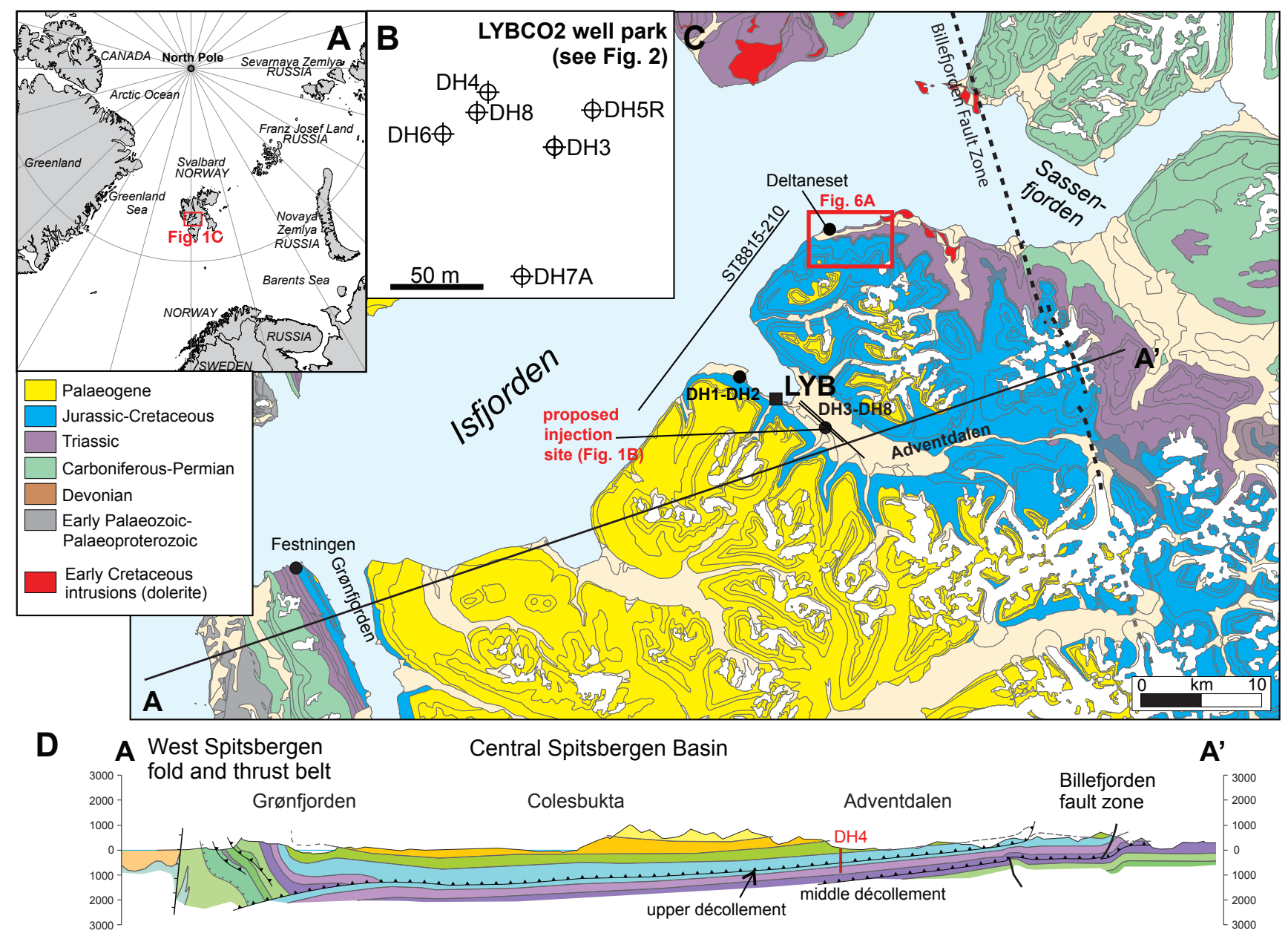

Figure 1. Geological overview of the study area, adapted from Koevoets et al. (2018). (A) Location map of the Svalbard archipelago, with the study area highlighted by the red rectangle. (B) Expanded plan view of the UNIS $\mathrm{CO}_{2}$ lab well park in Adventdalen, where six wells were drilled in close proximity to each other. (C) Geological map of the study area, including the location of the studied outcrop at Deltaneset, data courtesy of Norwegian Polar Institute. Selected 2D seismic profiles presented in Fig. 5 are indicated, the full 2D seismic coverage is provided in Bolum et al. (2012), Senger et al. (2013) and Anell et al. (2014). (D) Regional cross-section across the Central Spitsbergen Basin illustrating the southwesterly regional dip in the study area, modified after Dallmann (2015). The stratigraphy penetrated by the deepest well in the UNIS CO lab well park ('proposed injection site' on the map), DH4, is marked on the cross-section.

highlight that the target reservoir is compartmentalised to the extent that two wells $94 \mathrm{~m}$ apart are not in direct communication and, thus, lateral flow barriers must be present (Senger et al., 2015; Mulrooney et al., 2019). 2D seismic data covering the injection site do not show any large-scale normal faults in the area (Bælum et al., 2012; Anell et al., 2014; Tsuji et al., 2016). Only low-angle décollements and associated thrust faults are present (Blinova et al., 2013; Roy et al., 2014; Beka et al., 2017). Nonetheless, detailed field mapping of the outcropping reservoir at Konusdalen $15 \mathrm{~km}$ northeast of the planned injection site reveals a series of normal faults that are likely to contribute to reservoir compartmentalisation (Ogata et al., 2014b; Mulrooney et al., 2019).

\section{Data and methods}

Fig. 3 illustrates the applied integrated workflow from outcrop to synthetic seismic data. In essence, we integrate geometrical properties of fault zones from the outcrops with realistic elastic properties from the boreholes drilled at the UNIS $\mathrm{CO}_{2}$ lab well park in Adventdalen (Fig. 1B). The resulting elastic property models serve as input for seismic modelling with increasing complexity; from simple models with constant background elastic properties, through layered models with elastic properties extrapolated from well data to models with random seismic noise added (Table 1). 


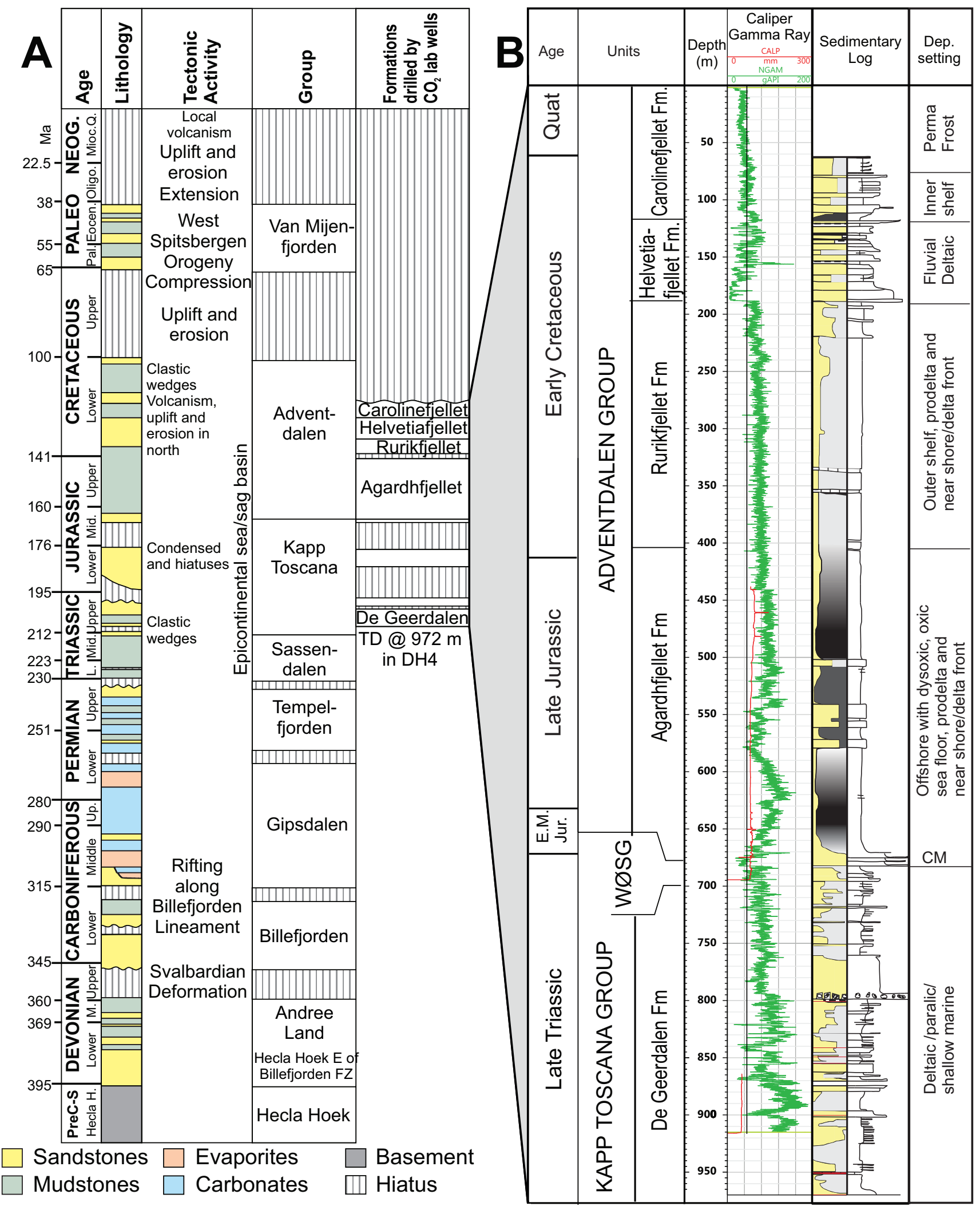

Figure 2. Regional and local stratigraphy of the study area. (A) Regional stratigraphic column, adapted from Nøttvedt et al. (1993). (B) Overview of the stratigraphy penetrated by the DH4 borehole in the UNIS $\mathrm{CO}_{2}$ lab well park; lithological log modified after Atle Mørk, wireline logging by Harald Elvebakk (Geological Survey of Norway). WØSG = Wilhelmøya Subgroup. 


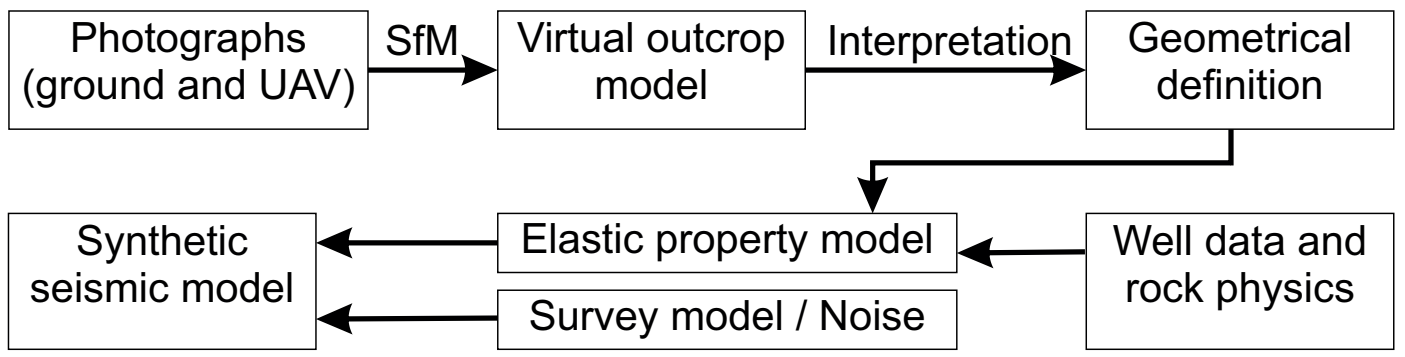

Figure 3. Summary of applied workflow. SfM - Structure-from-motion. UAV - unmanned aerial vehicle.

Table 1. Summary of tested geological models. Each model has the same geometry, but $\mathrm{CO}_{2}$ is substituted for brine in the reservoir and within the hypothetical fault defined in the caprock by an increase of porosity. The $\mathrm{CO}_{2}$ evolution in the simple (S) models is displayed in Fig. $7 B$. The $\mathrm{CO}_{2}$ evolution in the layered $(L)$ models is displayed in Fig. $7 D$.

\begin{tabular}{|c|c|c|c|c|c|}
\hline Model name & Geological complexity & Geometry & Fluid presence & Noise & Results shown \\
\hline S1 & Simple & Fig. 7B (1) & Brine in entire model & No & Fig. 10A \\
\hline $\mathrm{S} 2$ & Simple & Fig. 7B (2) & $\mathrm{CO}_{2}$ in Wilhelmøya subgroup, brine elsewhere & No & Fig. 10B \\
\hline S3 & Simple & Fig. 7B (3) & $\mathrm{CO}_{2}$ in Wilhelmøya and plume in De Geerdalen & No & Fig. 10C \\
\hline S4 & Simple & Fig. 7B (4) & Start of the $\mathrm{CO}_{2}$ migration in the caprock fault & No & Fig. 10D \\
\hline S5 & Simple & Fig. 7B (5) & Progress of the $\mathrm{CO}_{2}$ in the fault & No & Fig. 10E \\
\hline S6 & Simple & Fig. 7B (6) & Reservoir and fault filled with $\mathrm{CO}_{2}$ & No & Fig. 10F \\
\hline $\mathrm{L} 1$ & Layered & Fig. 7C & Brine in all the model & No & Fig. 12C \\
\hline $\mathrm{L} 2$ & Layered & Fig. 7C & $\mathrm{CO}_{2}$ in Wilhelmøya and the fault in the caprock & No & Fig. 12D \\
\hline L1n & Layered & Fig. 7C & Brine in all the model & Yes & Fig. 12E \\
\hline $\mathrm{L} 2 \mathrm{n}$ & Layered & Fig. 7C & $\mathrm{CO}_{2}$ in Wilhelmøya and the fault in the caprock & Yes & Fig. 12F \\
\hline
\end{tabular}

\section{Virtual outcrop modelling}

Structure-from-motion (i.e., photogrammetry; Westoby et al., 2012) has become an increasingly popular method for efficiently generating accurate $3 \mathrm{D}$ georeferenced outcrop models (Fig. 4), comparable in quality to terrestrial lidar scanning (Buckley et al., 2008). Photogrammetric datasets were acquired in three approximately $\mathrm{N}-\mathrm{S}$-trending valley sections south of Deltaneset (location shown in Fig. 1). In all cases, the east-facing cliff sections showing the faults were imaged with a hand-held SLR camera (Canon 6D, 21MP and Nikon D5300, 24MP) with a built-in GPS module. The virtual outcrop model generation was conducted using Agisoft PhotoScan Professional (v. 1.3.4), applying standard photogrammetric processing steps, including image alignment, dense point cloud generation, meshing and texturing (Fig. 4; Westoby et al., 2012). Outcrop models were analysed in Lime, a virtual outcrop interpretation package, allowing outcrop measurements including distance and surface orientation (i.e., dip azimuth and angle) calculated from three selected points. Field data were used for quality control.

\section{Seismic modelling}

Seismic modelling ranges from computationally intensive full-wavefield modelling in rather detailed models, via faster technology such as standard ray tracing only valid for smoother structures, to the simple and very efficient $1 \mathrm{D}$ convolution approach. $1 \mathrm{D}$ convolution cannot, however, account for geologically complex settings, i.e., laterally varying structures (Lecomte et al., 2015). Alternatively, a $3 \mathrm{D}$ ray-based convolution modelling approach involving point-spread functions (PSF) is similar in efficiency and ease-of-use to $1 \mathrm{D}$ convolution, while adding survey- and model-dependent resolution and illumination effects (Lecomte, 2008; Lecomte et al., 2016). The PSF is the 3D convolution kernel applied to a 3D input reflectivity model, instead of only using a wavelet as convolution kernel in a 1D convolution performed trace by trace. It corresponds to the theoretical response of a point scatterer (diffraction point) after pre-stack depth migration (PSDM); it does contain the wavelet, like 1D convolution, but also other key parameters constraining illumination and resolution of a seismic acquisition and imaging. Note that the PSFbased convolution modelling, as applied in this study, generates seismic images corresponding to PSDM 


\section{Image processing:}
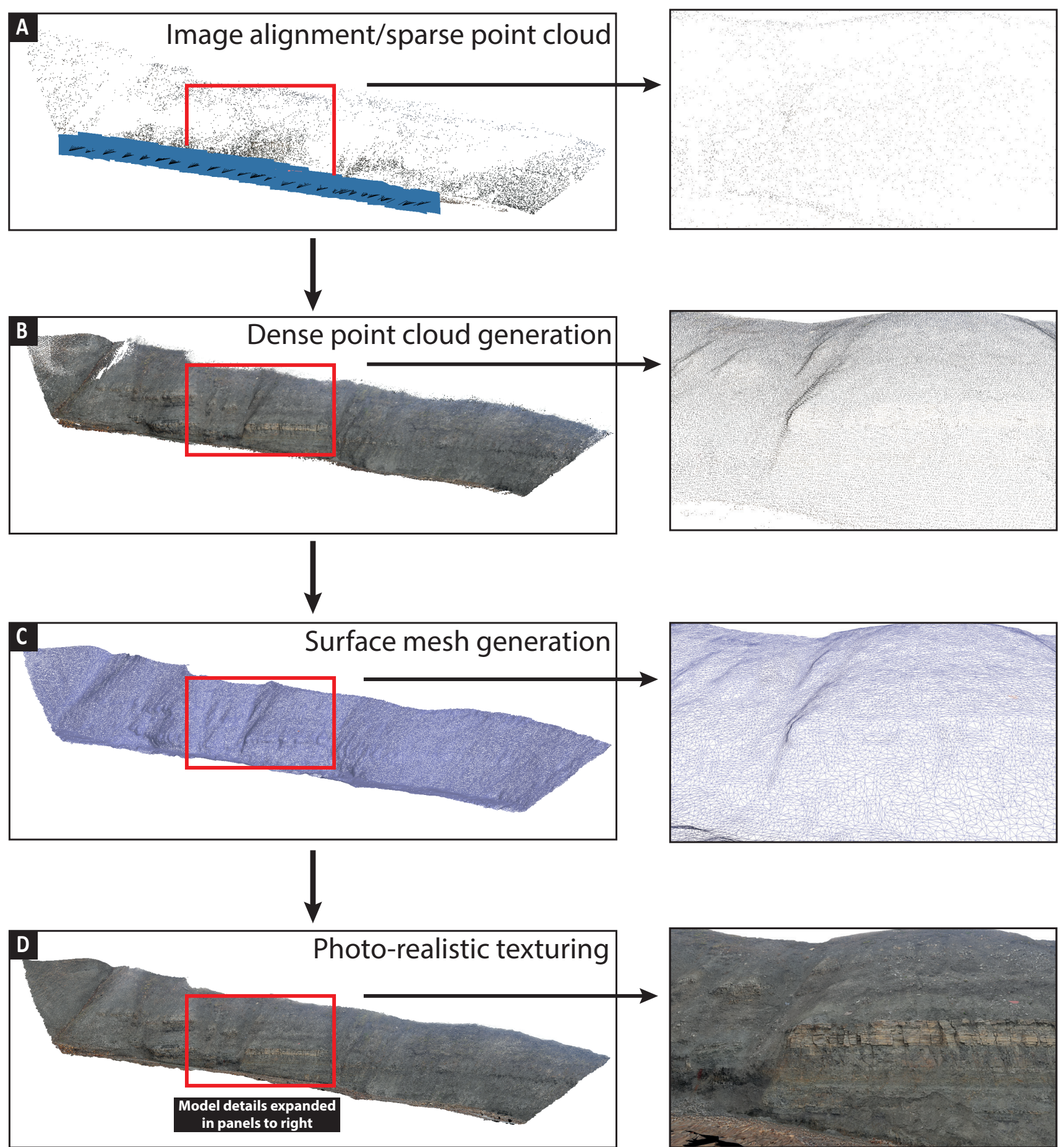

Figure 4. Virtual outcrop model generation workflow for the Konusdalen outcrop of the fault-affected Wilhelmøya Subgroup. Georeferenced high-resolution oblique images were captured with a high degree of overlap (approx. 80\%) using both hand-held and UAV-borne cameras. Images are imported to Agisoft PhotoScan Professional (version 1.3.4), which incorporates the structure-from-motion algorithm. Point matching algorithms allow similar features in multiple images to be matched and allow creation of spatially referenced sparse (A) and subsequently dense point clouds (B). The point cloud is used to create a mesh surface of the virtual outcrop $(C)$, upon which the original photographic imagery is draped (D) to result in a photo-realistic virtual outcrop model suitable for further analyses.

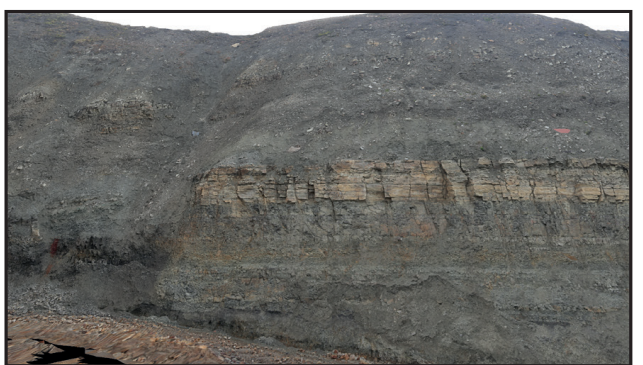

detail:

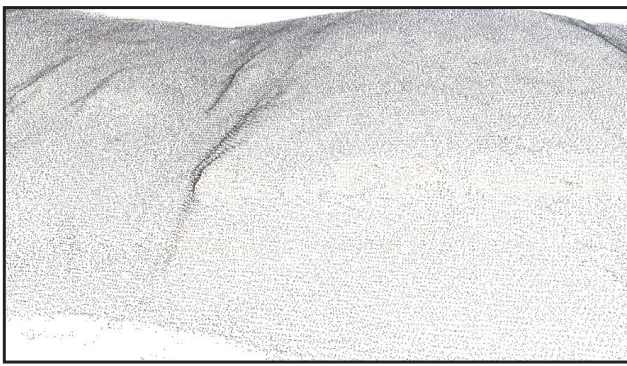


images, i.e., with a true depth axis and no time-distortion effects. To simulate the latter, depth-to-time conversion could be used, but is not the focus of the present work.

We first perform a detailed seismic amplitude study focusing on recognising the presence of $\mathrm{CO}_{2}$ in a simple structural model, i.e., without including spatial variation of the elastic parameters in the 'background' away from the features of interest (i.e., $\mathrm{CO}_{2}$-filled segments including faults). This approach provides the theoretical seismic imaging capacities of the target reservoir beneath the caprock and, thus, the impact of the $\mathrm{CO}_{2}$ injection within the reservoir can be analysed. We design a PSDM filter in the wavenumber domain, before applying a Fourier Transform to obtain the corresponding PSF in the spatial domain (Lecomte et al., 2016). Subsequently, we define a more realistic model including vertically layered elastic parameters from well data to integrate the effect of realistic geology and further appreciate the detectability of the $\mathrm{CO}_{2}$ signal within surrounding structures. Finally, we add noise to the modelling results to evaluate further if the $\mathrm{CO}_{2}$ signal would be visible in real data. The different approaches and models run are listed in Table 1.

\section{Rock physics modelling}

The structural models gained from virtual outcrop modelling are populated with realistic elastic properties based on wireline data acquired from the slimhole wellbore DH4 (Elvebakk, 2010). There is full P-wave velocity $\left(\mathrm{V}_{\mathrm{p}}\right)$ and $\mathrm{S}$-wave velocity $\left(\mathrm{V}_{\mathrm{s}}\right)$ coverage in the zone of interest. Density was measured using a trisonde density probe down to $700 \mathrm{~m}$ depth and represents a qualitative reading only (Elvebakk, 2010). To generate a quantitative density curve, the curve was calibrated to core plug density measurements (Johnsen \& Skurtveit, 2010). This density curve is used to estimate a porosity curve, which is then compared to core plug measurements from the reservoir section (Mørk, 2013; Senger et al., 2015).
The elastic parameter values used in the modelling are listed in Table 2. To predict elastic parameters, the Gassmann equations (Gassmann, 1951) are employed as described in Lubrano-Lavadera et al. (2018). The confinement and pore pressures are 18.2 $\mathrm{MPa}$ and $7 \mathrm{MPa}$, respectively, and the temperature is $25^{\circ} \mathrm{C}$. A shale facies is considered for the caprock and sandstone facies for the reservoir. The dry frame parameters are computed from the log data for each layer. The predicted P-wave and S-wave velocities are superimposed on the $\mathrm{Vp}$ and Vs logs. They represent a reasonable fit between wireline data and predicted properties. To properly consider the effect of $\mathrm{CO}_{2}$ injection in the target reservoir, we compute the bulk modulus and density of the $\mathrm{CO}_{2}$ for appropriate pressure and temperature conditions of the reservoir using Span \& Wagner (1996). In this study, we do not use intermediate values for $\mathrm{CO}_{2}$ saturation, since seismic data cannot constrain the saturation itself, only the presence and absence of $\mathrm{CO}_{2}$ (Lubrano-Lavadera et al., 2018). Thus, a $\mathrm{CO}_{2}$ saturation of $0 \%$ is employed for the parts of the model saturated with brine, and a $\mathrm{CO}_{2}$ saturation of $100 \%$ is used in the model segments containing $\mathrm{CO}_{2}$.

\section{Structural characterisation and geomodelling}

\section{Seismic-based fault interpretation}

Existing onshore and offshore 2D seismic data were constrained by both the DH4 borehole in Adventdalen and the regional geology and interpreted (Fig. 5). The dominant frequency of the presented data is typically 25 $\mathrm{Hz}$ for the commercial surveys (ST8815 and NH8802) and $35 \mathrm{~Hz}$ for the UNIS survey. Assuming a P-wave velocity of $4 \mathrm{~km} / \mathrm{s}$, representative of the highly lithified sediments of the study area (Bælum \& Braathen, 2012; Bælum et al., 2012; Anell et al., 2014), this results in a vertical resolution of $40 \mathrm{~m}$ and $28.5 \mathrm{~m}$, respectively. More recent targeted 2D seismic acquisition (Tsuji et al., 2016)

Table 2. Elastic parameters used to characterise different zones in the seismic models S1 to S6.

\begin{tabular}{lrcccc}
\hline & & Porosity $(\%)$ & $V_{p}(\mathrm{~km} / \mathrm{s})$ & $V_{s}(\mathrm{~km} / \mathrm{s})$ & Density $\left(\mathrm{g} / \mathrm{cm}^{3}\right)$ \\
\hline Caprock (C1): & matrix:brine & 1,0 & 3.35 & 1.64 & 2.58 \\
& fault: brine & 2,0 & 3.30 & 1.63 & 2,57 \\
& $\mathrm{CO}_{2}$ & 2,0 & 3.05 & 1.64 & 2.57 \\
Upper part of Wilhelmøya Subgroup & matrix:brine & 15,0 & 4.05 & 2.21 & 2.41 \\
(R1): & $\mathrm{CO}_{2}$ & 15,0 & 3.95 & 2.23 & 2.36 \\
& fault: brine & 16,0 & 4.05 & 2.21 & 2.39 \\
Lower part of Wilhelmøya Subgroup and & matrix:brine & 10,0 & 3.95 & 2.23 & 2.35 \\
the underlying De Geerdalen Formation & $\mathrm{CO}_{2}$ & 16,0 & 4.18 & 2.31 & 2.46 \\
(R2): & $\mathrm{CO}_{2}$ & 10,0 & 4.06 & & 2.32 \\
\hline
\end{tabular}




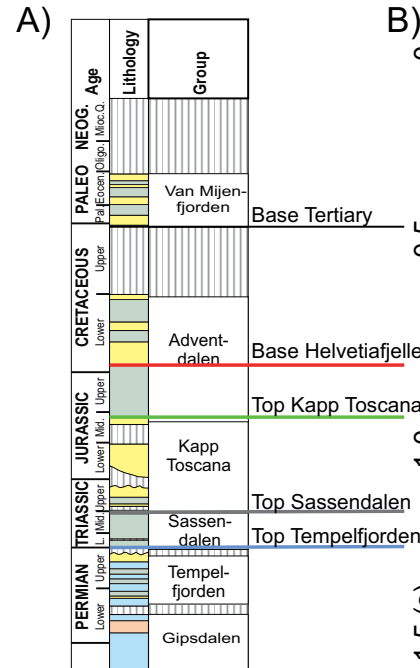

D) Tsuji et al. (2016) 雨 DH4

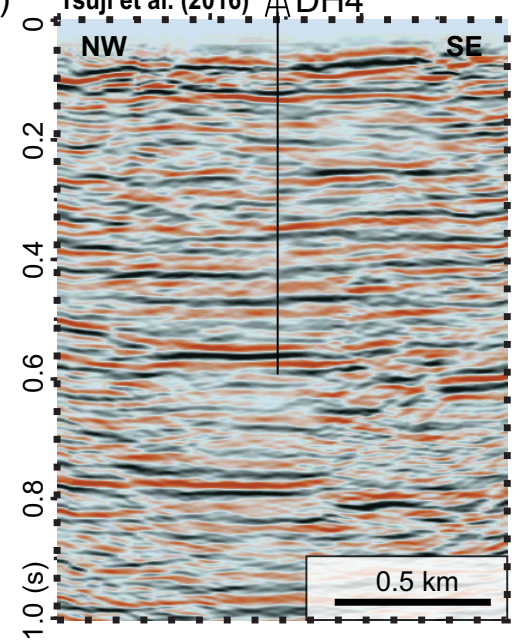

B) $\mathrm{NH8802-03}$

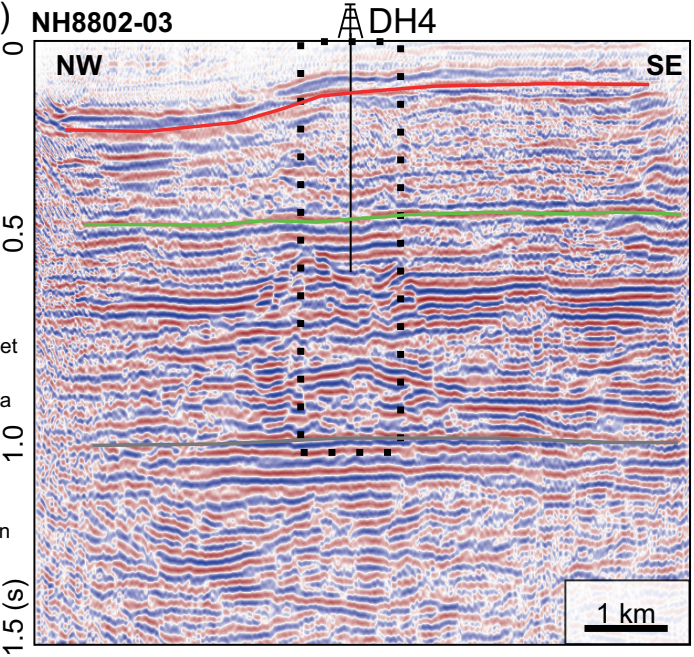

E) $\mathbf{s T 8 8 1 5 - 2 1 0}$

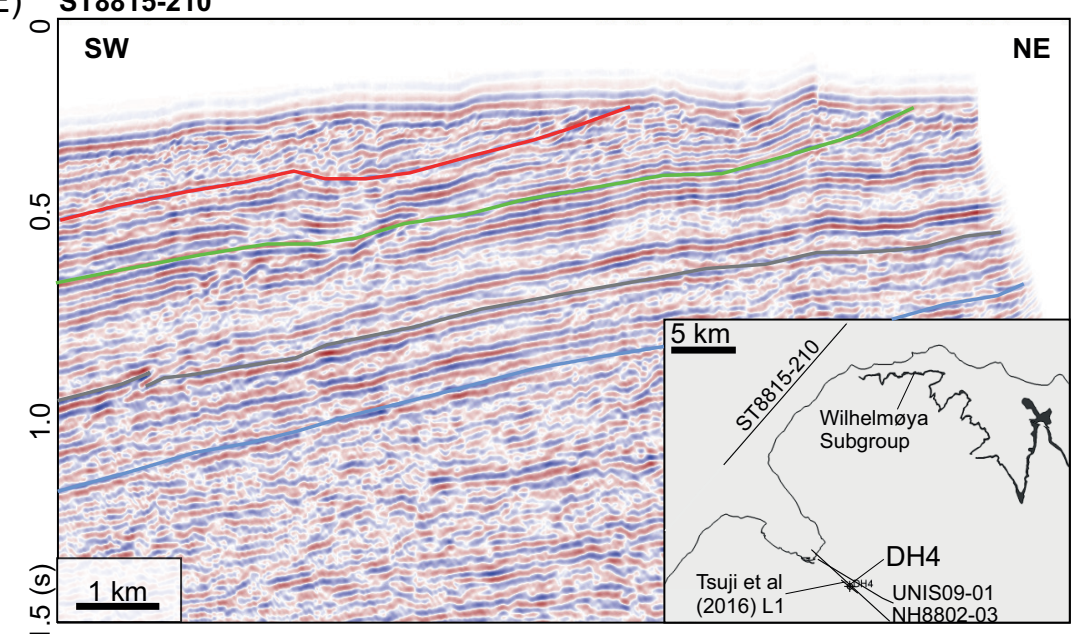

Figure 5. 2D seismic profiles from the study area. (A) Stratigraphic column with the major seismic reflections expected to be interpretable within the study area. The onshore profiles NH8802-03 (B) and UNIS09-01 (C) image similar stratigraphy in the vicinity of the $972 \mathrm{~m}$-deep DH4 borehole. Acquisition parameters from the $1.2 \mathrm{~km}$-long high-resolution profile (D) presented by Tsuji et al. (2016) are used to constrain the realistic modelling scenario. The dashed rectangles in B and C indicate the position of the Tsuji et al. (2016) profile in relation to the NH8802-03 and UNIS09-01 profiles. (E) The marine profile ST8815-210 illustrates the dipping nature of the reservoir-caprock system towards the southwest.

provides improved resolution, but is spatially limited to the near-well area. No tectonic features on the order of tens of metres offset have been identified along the reservoir-cap rock interface in the field, and it is thus not surprising that the seismic profiles are dominated by parallel reflections, which are only locally disturbed by the presence of thrusts and back-thrusts (Blinova et al., 2013) as well as igneous intrusions (Senger et al., 2013).

\section{Outcrop-based fault characterisation}

Extensional fault systems were identified in the eastfacing outcrops along the three river valley sections (Fig. 6A). Virtual outcrop models generated for these outcrops (Fig. 6B, D) were used to accurately determine the orientation and spacing of faults, the results of which are used as input for seismic modelling. Faults affect the target storage formation (Fig. 6B) in Konusdalen, where three rotated fault blocks ranging from 2 to $6 \mathrm{~m}$ in width are recognised. These fault blocks define a $2 \mathrm{~m}$-wide graben and an $11 \mathrm{~m}$-wide horst. The faults strike NESW to ENE-WSW and dip approximately $65^{\circ}$ towards NW-NNW. Antithetic faults are slightly steeper, with dips of approximately $70^{\circ}$ towards SE-SSE. These faults, while exhibiting minor offsets, have been suggested to compartmentalise the reservoir at the UNIS $\mathrm{CO}_{2}$ lab well park and prevent across-fault fluid migration (Mulrooney et al., 2019).

Faults affecting the caprock interval are observed in a valley $1.5 \mathrm{~km}$ to the east of Konusdalen informally named 'Criocerasdalen' by Mulrooney et al. (2019), and in a valley $1 \mathrm{~km}$ to the west, hereafter referred to as 'Konusdalen-West'. In Criocerasdalen (Fig. 6C), these faults show wider spacing (in the range of 25 and $45 \mathrm{~m}$ ) than the faults in the reservoir and lower angle dips (approximately $25^{\circ}$; Fig. 6C, D). The faults in 

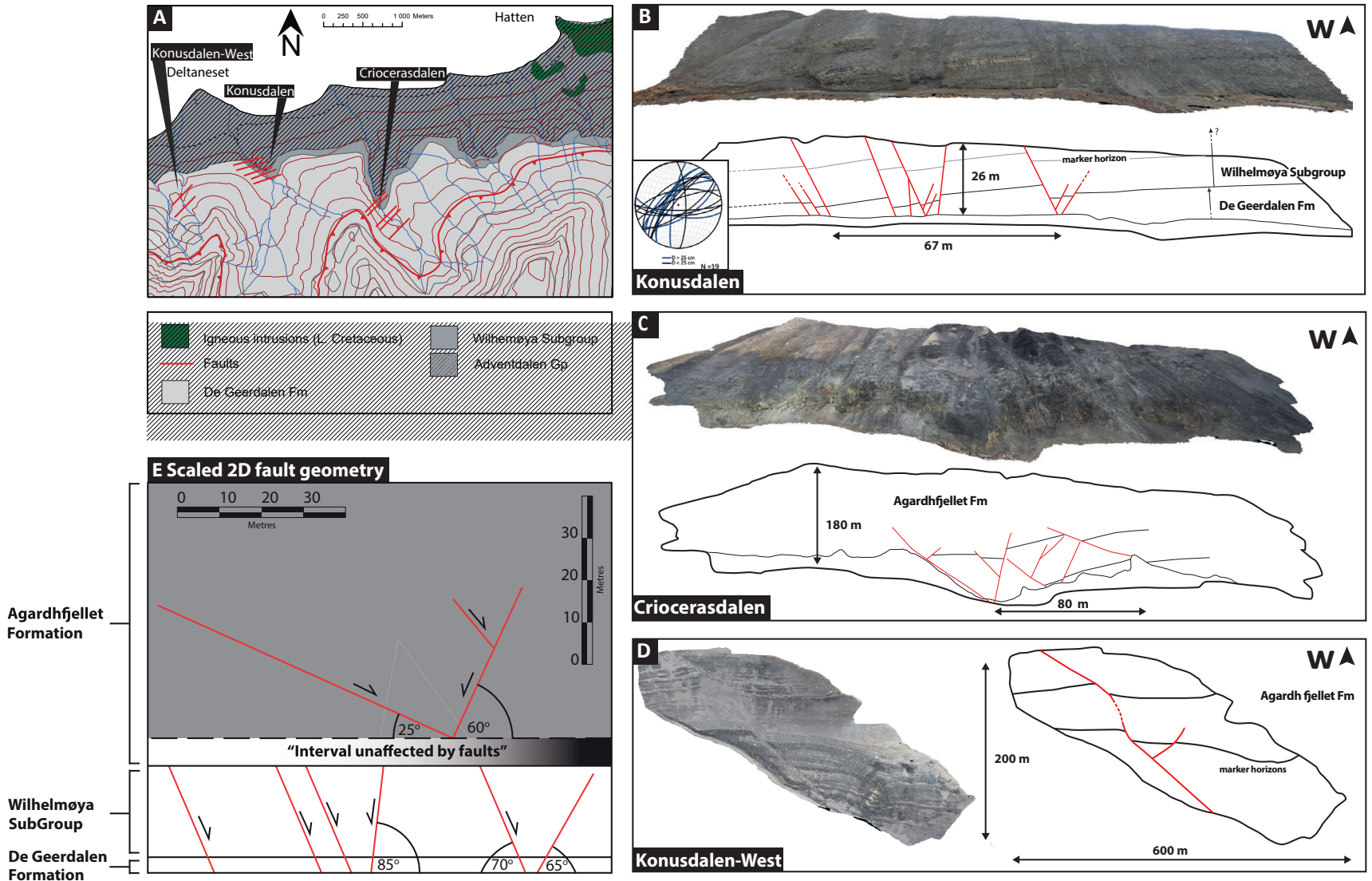

Figure 6. (A) Location of three east-facing outcrops of the target formations for which virtual outcrop models were generated. (B) Storage formation (Konusdalen), (C) caprock (Criocerasdalen) and (D) caprock (Konusdalen-West). The inset stereoplot in (B) shows that the normal faults predominately strike NE-SW to ENE-WSW and have displacements down to the NW to NNW. Images of the virtual outcrops are shown with line drawings of the main faults. Marker horizons are highlighted to show offset. (E) Scaled 2D fault geometric framework used as input for seismic modelling, with closely spaced, high-angle faults in the storage formation and wider-spaced, lower-angle faults affecting the caprock.

Criocerasdalen strike approximately $10^{\circ}$ anticlockwise to the underlying system. A single fault with a minor antithetic splay is observed within the caprock in Konusdalen-West (Fig. 6D) and exhibits a similar strike and low-angle dip as the Criocerasdalen faults. Given that displacement on faults in Criocerasdalen tips out down section within the lower Agardhfjellet Fm, and that the Konusdalen faults tip out up section approximately $10 \mathrm{~m}$ below the interface between the Wilhelmøya Subgroup and the Agardhfjellet Fm, it is apparent that both fault systems are not hard linked (Fig. 6E). Fault complexity, i.e., minor slip surface and damage zones adjacent to faults, has been described by Mulrooney et al. (2019), but is below the resolution of the input model for this study (Fig. 6E).

\section{Geological scenarios and model geometry}

Table 1 summarises all models conducted in this study. The main feature observed in the outcrops is structural decoupling across the reservoir-caprock interface, manifested by compartmentalising normal faults in the Wilhelmøya Subgroup and lower-angle detachment faults in the Agardhfjellet Fm caprock. To represent these critical elements within a realistic model of the UNIS $\mathrm{CO}_{2}$ lab well park, three hypothetical compartments within the upper reservoir are defined, connected by a normal fault with vertical offset between compartments of c. 10 metres (Fig. 7). To represent the fault in the caprock, a linear feature with higher porosity compared to the surroundings is defined under the assumption that enhanced fracturing in the fault's damage zone will enhance porosity. Since only limited petrophysical information from faults in the shaledominated succession is available, we considered this to be a reasonable assumption, although faults could represent both barriers and migration pathways to fluid flow depending on a range of geological factors (e.g., cementation, offset, lithology, depth, in situ stresses, timing and duration of fault activity).

Furthermore, a symmetrical $\mathrm{CO}_{2}$ plume in the underlying De Geerdalen Fm reservoir is assumed in order to test the detectability of such a feature. The plume size, c. 768,000 $\mathrm{m}^{3}$ fully saturated with $\mathrm{CO}_{2}$, would equate to c. 5,000-62,000 tons of $\mathrm{CO}_{2}$ for the low and high $\mathrm{CO}_{2}$ density cases presented by Senger et al. (2015), respectively. For comparison, Longyearbyen's power 


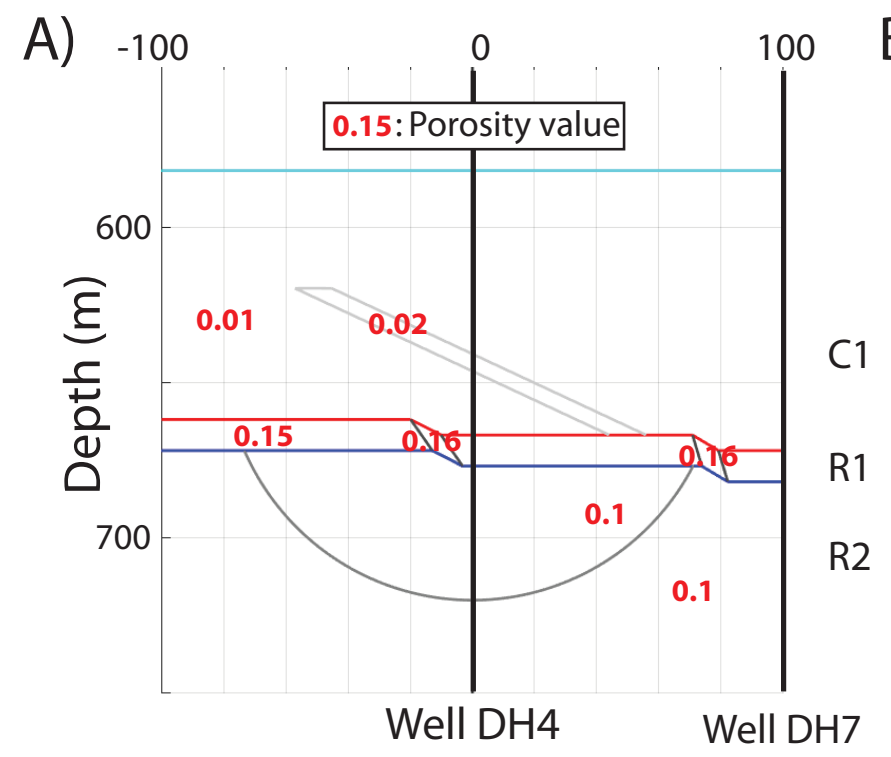

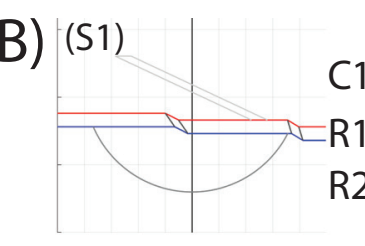
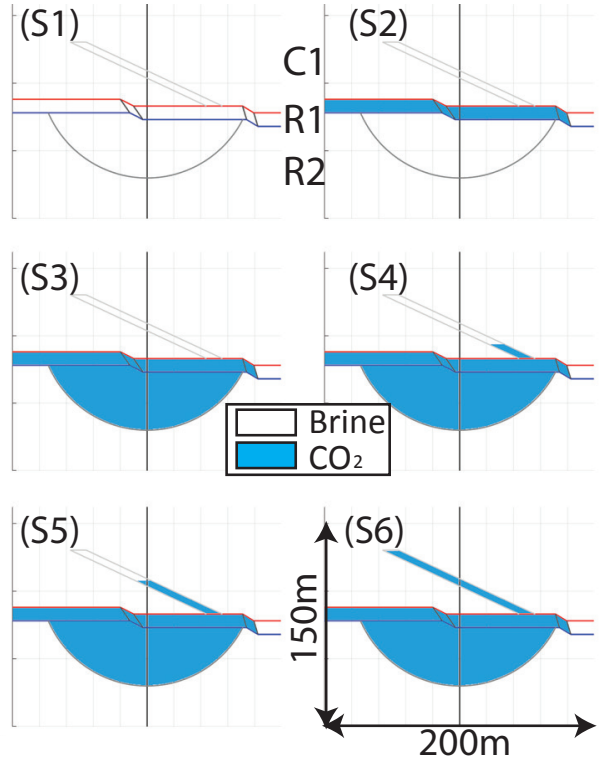

C)

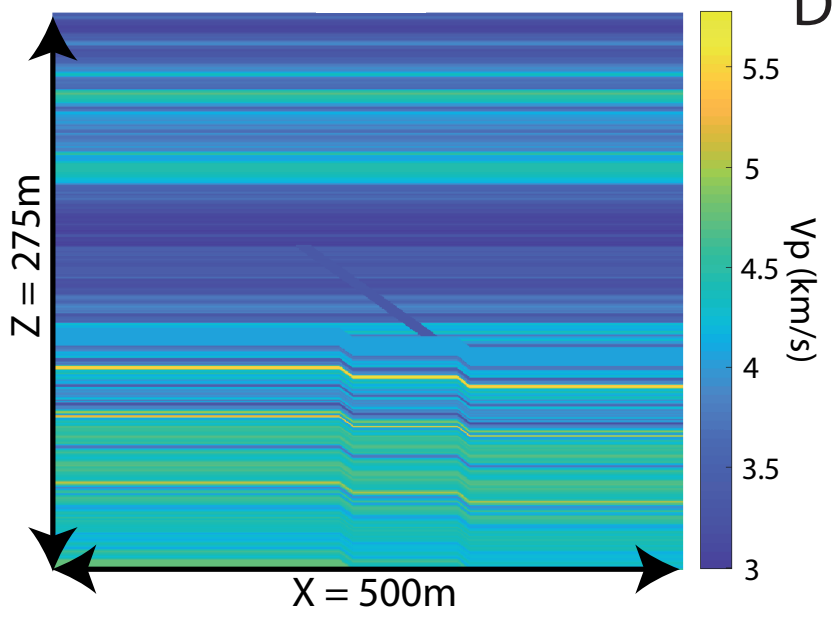

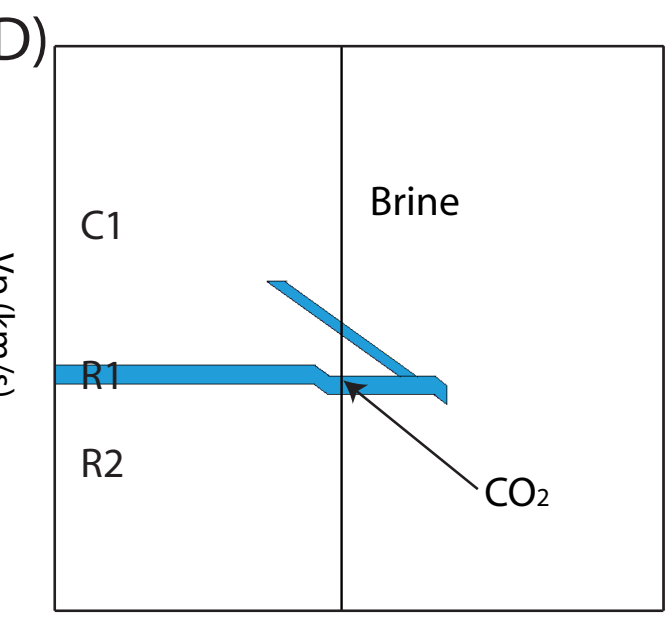

Figure 7. (A) Reservoir and caprock model. The light blue line represents the top of the model, with the actual caprock extending $c .200 \mathrm{~m}$ further up, (B) $\mathrm{CO}_{2}$ volume evolution within the reservoir and intruding into a fault within the caprock. Numbers 1-6 correspond to the seismic modelling results shown in Fig. 10. (C) Layered $V_{p}$ model. Similar well-log derived models are available for $V_{s}$ and density. (D) $\mathrm{CO}_{2}$ distribution in the Wilhelmøya Subgroup and the caprock fault used for models L2 and L2n. C1 - caprock, R1-upper part of the Wilhelmøya Subgroup characterised by higher porosity, R2 - Lower part of the reservoir, including the lower part of the Wilhelmøya Subgroup and the underlying De Geerdalen formation.

plant emitted c. 70,000 tons of $\mathrm{CO}_{2}$ in 2016. To simulate $\mathrm{CO}_{2}$ injection within this reservoir, brine is substituted with $\mathrm{CO}_{2}$ in different parts of the reservoir.

The model thus created remains simplistic and it will be difficult to compare it to actual seismic data. To include the complexity of seismic wave velocities $\left(\mathrm{V}_{\mathrm{p}}, \mathrm{V}_{\mathrm{s}}\right)$ and the density observed in the log (Fig. 8), and thus design a more realistic representation of the host rock, we define a layered model employing thin horizontal layers in both the caprock and reservoir (Fig. 7C). Note that although only $\mathrm{V}_{\mathrm{p}}$ is displayed, $\mathrm{V}_{\mathrm{s}}$ and density profiles are constructed accordingly. However, since the focus of this more elaborate model employed in models L1 and L2 is to study the effect of $\mathrm{CO}_{2}$ substitution at the caprock/ reservoir contact on seismic data as well as $\mathrm{CO}_{2}$ leakage through faults, we assume that only the upper part of the
Wilhelmøya Subgroup reservoir ( $\mathrm{R} 1$ on Fig. 8) as well as the fault within the Agardhfjellet Fm are saturated with $\mathrm{CO}_{2}$ and omit the plume within the De Geerdalen Fm (Fig. 7D).

\section{Seismic modelling}

\section{PSDM filter design}

We first compose a PSDM filter using the seismic acquisition parameters employed in the $2 \mathrm{D}$ seismic survey recorded in 2010 (Tsuji et al., 2016), this in order to get the corresponding illumination and resolution pattern. The considered seismic line is $1.2 \mathrm{~km}$ long with 


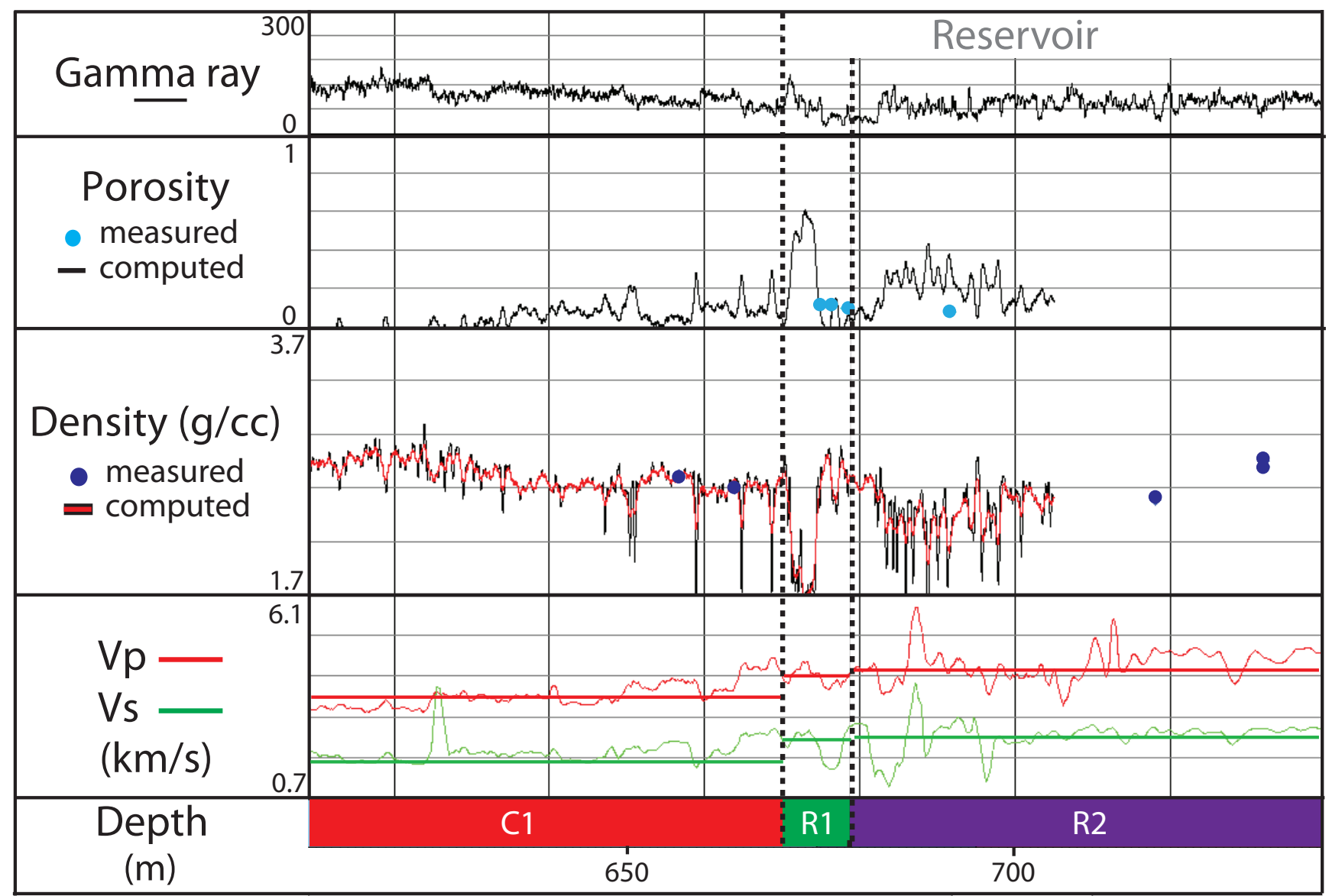

Figure 8. Relevant wireline logs in DH4 and computed density and porosity used for the seismic modelling. Wireline logging conducted by the Geological Survey of Norway (Elvebakk, 2010). The constant velocity in the lower log $\left(V_{p}, V_{s}\right)$ used in models S1 to S6 can be found in Table 2. The values displayed here are representative for reservoir and caprock filled with brine.

shot spacing of $25 \mathrm{~m}$. It is oriented approximately NWSE and thus perpendicular to the fault presented in Fig. 6B. The snowstreamer used in acquisition consisted of groups of 8 geophones over an interval of $25 \mathrm{~m}$, and the acquisition was similar to that described by Johansen et al. (2011). In order to investigate the effect of the overburden, we use the 3D background velocity model described in Lubrano-Lavadera et al. (2018). Assuming a $50-\mathrm{Hz}$ zerophase Ricker wavelet as source signal, the PSDM filter was computed by ray tracing within the background velocity model and in accordance with the survey geometry, but selecting only the small incident angles (i.e., small offsets as a proxy of a zero-offset case) for simplicity (Fig. 9A). The survey- and model-dependent PSDM filter shows irregularities due to the discrete sampling imposed by the discrete geophone and shot locations. These may induce acquisition-geometry dependent imaging noise, which can commonly be observed in real seismic data. However, since the analysis of such noise is not part of our study, we replace the survey- and model-dependent PSDM filter by a matching analytical filter.

To compute an analytical PSDM filter, the necessary parameters are the maximum reflector dip to image, the average velocity in the target, an incident angle and a wavelet (Lecomte et al., 2016). We use a maximum illumination dip of $60^{\circ}$ estimated from the 2010 survey parameters (extracted as the opening of the filter in Fig. $9 A$ ), an average $V_{p}$ velocity of $4 \mathrm{~km} / \mathrm{s}$ measured in the DH4 well (Fig. 8), an incident angle of $0^{\circ}$ (zero-offset case) and the same 50-Hz Ricker wavelet selected above. Fig. 9B presents the corresponding analytical PSDM filter and its associated PSF, in comparison with the surveyand model-dependent case (Fig. 9A). Being analytically designed, the PSDM filter does not contain acquisitiongeometry dependent effects and corresponds to a uniform illumination up to $60^{\circ}$ reflector dip in both directions. The associated lateral resolution pattern corresponds to about half of a wavelength, as generally observed in standard seismic surveys in relatively flat overburden, even after migration (Herron, 2011). A perfect illumination pattern (i.e., imaging dips up to vertical) would yield a lateral resolution of a quarter of a wavelength (as for the vertical resolution), but is usually not attainable. We thus prefer to retain a lateral resolution of only half a wavelength in order to check its impact on the $\mathrm{CO}_{2}$ signature when blending with the surrounding structures, especially with the layering introduced in the second set of structural models. Note that lateral resolution cannot be accounted for when only using $1 \mathrm{D}$ convolution. 

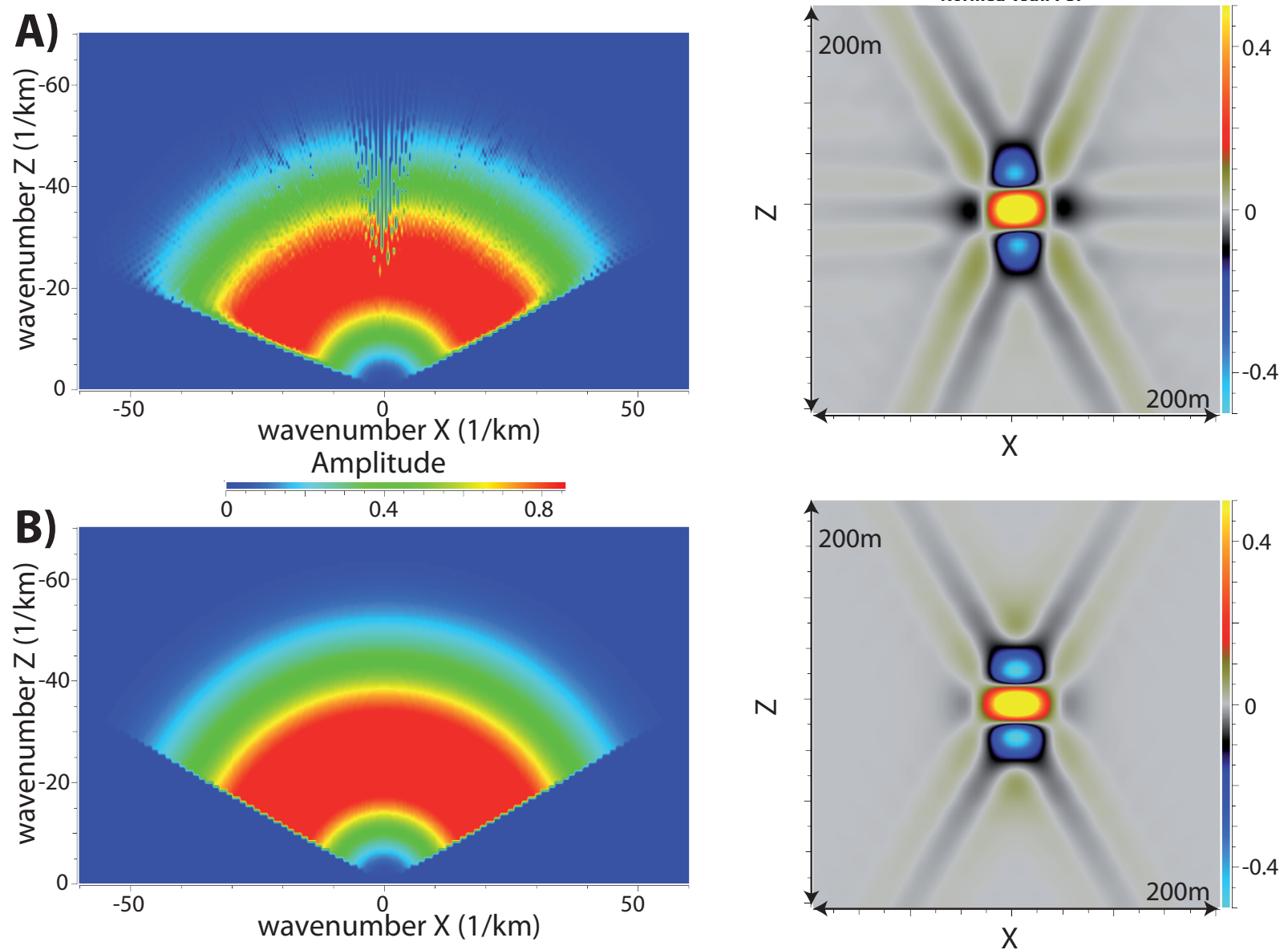

Figure 9. (A) Vertical cross-section of the PSDM filter (wavenumber domain, left) and corresponding PSF after Fourier transform of the PSDM filter (spatial domain, right) with parameters imitating the 2010 survey of Tsuji et al. (2016). (B) Analytical PSDM filter with maximum illumination dip of $60^{\circ}$.

In the following, all modelled PSDM images are amplitude-true, i.e., having a one-to-one relation with the input reflectivity. The amplitudes are calibrated in such a manner that a horizontal acoustic impedance contrast of reflectivity strength 1 results in a seismic reflector of amplitude 1 . This allows direct amplitude comparisons between all modelled scenarios, from the simple ones, via the layered ones and finally to the latter with the random noise added.

\section{Seismic imaging of $\mathrm{CO}_{2}$ migration through reservoir and fault}

The analytical PSF of Fig. 9B is first applied to the simplified reservoir models (Fig. 7B). Results are displayed in Fig. 10. To better illustrate the differences, three representative traces are extracted from each of these images to demonstrate the main features of the reservoir and reservoir/caprock interface reflections (Fig. 11). The first trace is located outside of the $\mathrm{CO}_{2}$ plume within the De Geerdalen Fm, but cuts through the $\mathrm{CO}_{2}$-saturated Wilhelmøya Subgroup. The second trace intersects all important model elements: caprock fault, reservoir and $\mathrm{CO}_{2}$ plume. The third trace crosses a part of the Wilhelmøya Subgroup not affected by $\mathrm{CO}_{2}$ injection.

The fault in the caprock, characterised by a higher porosity, appears in the PSDM images (Figs. 10A \& 11C). The fact that already a minor change in porosity, from 1 to $2 \%$ in the caprock and from 15 to $16 \%$ in the reservoir (Table 2), within a formation can trigger a seismic response is especially important in the studied low-matrix porosity succession. When the brine is substituted with $\mathrm{CO}_{2}$ in the caprock fault, the reflectivity increases and polarity changes. The seismic amplitude is doubled due to the combined effect of increased porosity and the presence of fluid. Thus, it appears possible to image a $\mathrm{CO}_{2}$-saturated fault zone though exact definition becomes difficult in the presence of geological complexity and noise (Fig. 12).

When the upper part of the Wilhelmøya Subgroup (R1) is examined, only one reflection appears in the seismic data (Figs. 10 \& 11), although there are two distinct interfaces in the reservoir, its top and base. This is due to limited seismic resolution as constrained by the PSF. Otherwise, the Wilhelmøya Subgroup reflection 


\section{A) model S1}

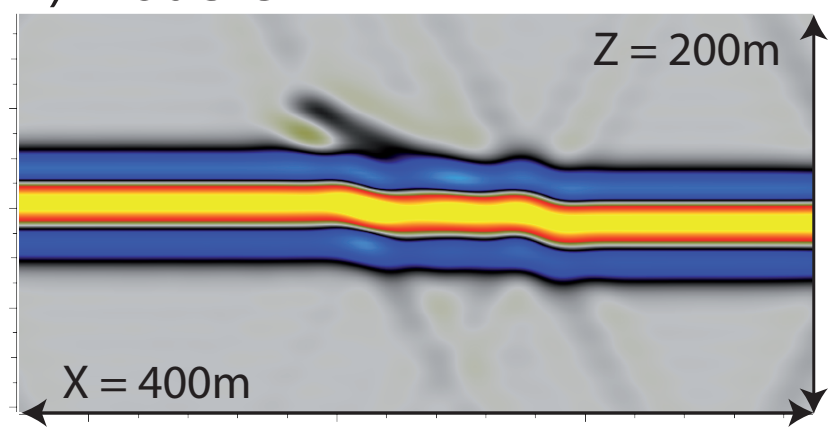

\section{C) model $\mathrm{S3}$}

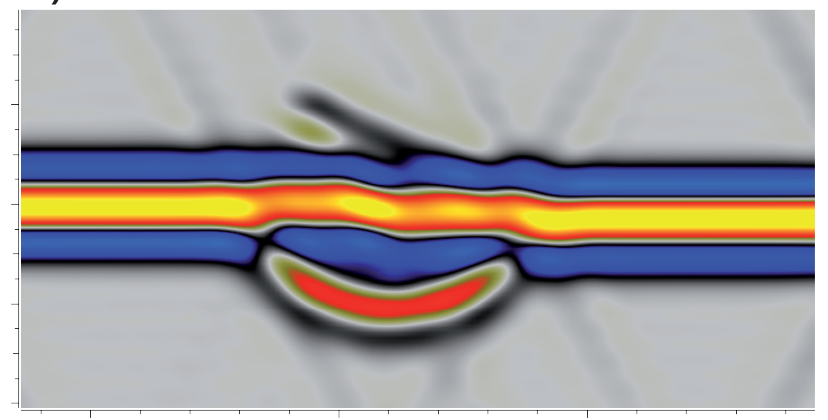

\section{E) model S5}

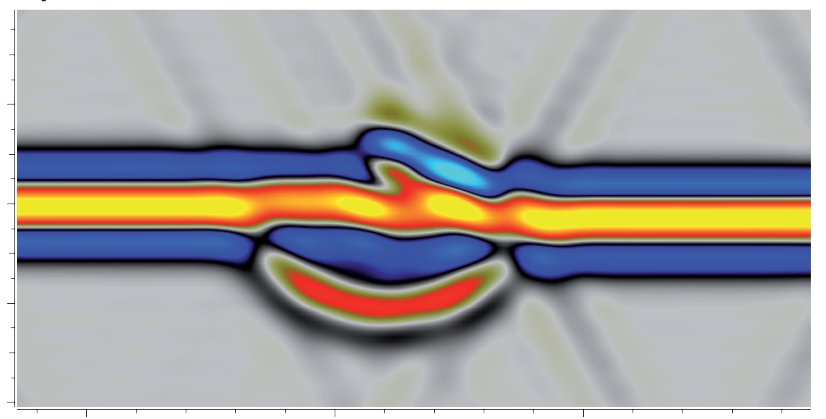

\section{B) model S2}

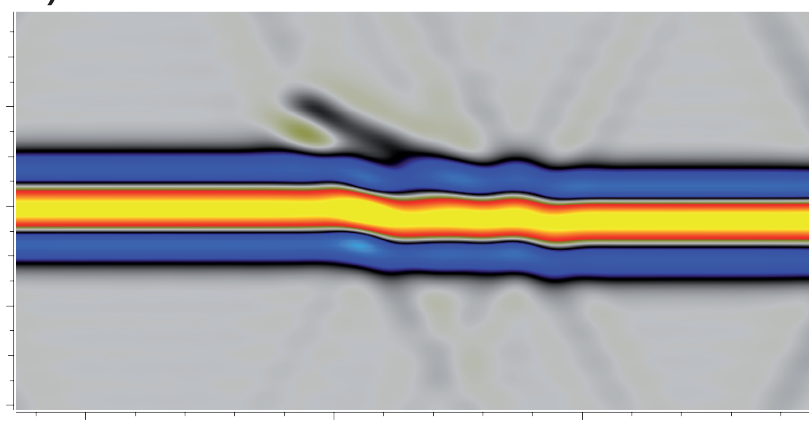

\section{D) model S4}

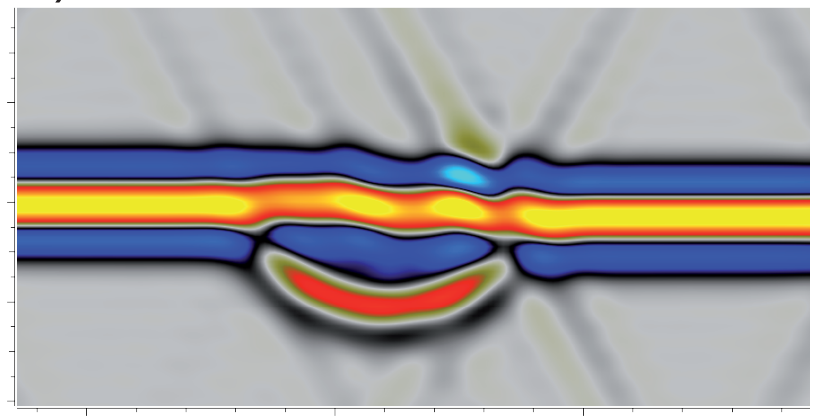

\section{F) model S6}

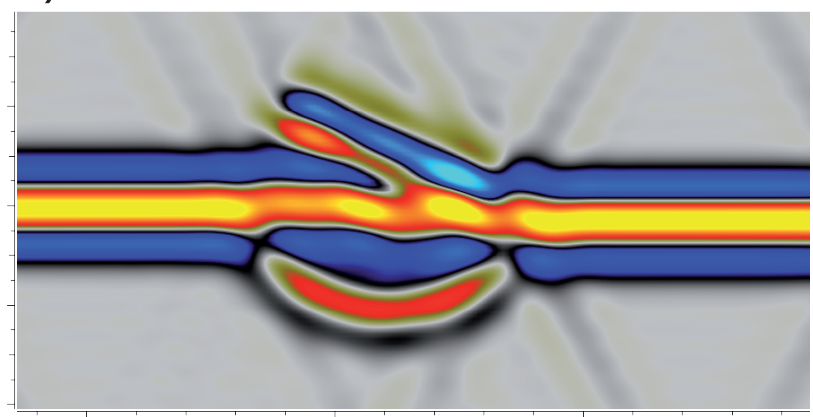

\section{Amplitude}

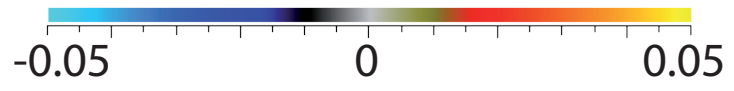

Figure 10. PSDM seismic sections for different $\mathrm{CO}_{2}$ distributions in the simple (S) models, (A) brine-filled reservoir, (B) $\mathrm{CO}_{2}$ injected into R1, (C) $\mathrm{CO}_{2}$ forming a plume in $\mathrm{R} 2$, (D) $\mathrm{CO}_{2}$ starting to migrate along a hypothetical fault in the caprock, (E) $\mathrm{CO}_{2}$ progressing within the fault and (F) $\mathrm{CO}_{2}$ filling the fault completely. The numbers in brackets indicate the start models presented in Fig. $7 \mathrm{~B}$. Further details on models $S 1$ to S6 are listed in Table 1, while elastic parameters are listed in Table 2.

amplitude does not seem to change with or without the presence of $\mathrm{CO}_{2}$ (Fig. 10A, B). A change appears with the migration of the plume (Fig. 10B, C). The traces in Fig. 11B-D present a decrease of amplitude and a small shift in the location of the peak. Therefore, an amplitude analysis of the reflection associated with the Wilhelmøya Subgroup will reveal the location of the lateral contact between $\mathrm{CO}_{2}$ and brine. The base of the $\mathrm{CO}_{2}$ plume located in the lower part of the reservoir (R2) is clearly visible (Figs. 10C, D \& 11C).
Effect of realistic geology and noise on seismic imaging

Subsequently, we consider the model characterised by surrounding thin layering in the host rock (Fig. 7C). The corresponding acoustic impedance distribution is illustrated in Fig. 12A. In addition, we generate a 'PSDMcoloured' noise model by convolving a white random noise grid (Gaussian distribution) with the analytical PSF to simply mimic imaging noise similar to the one recorded in actual data (Fig. 12B). This random noise thus has the frequency range of the seismic data, while 


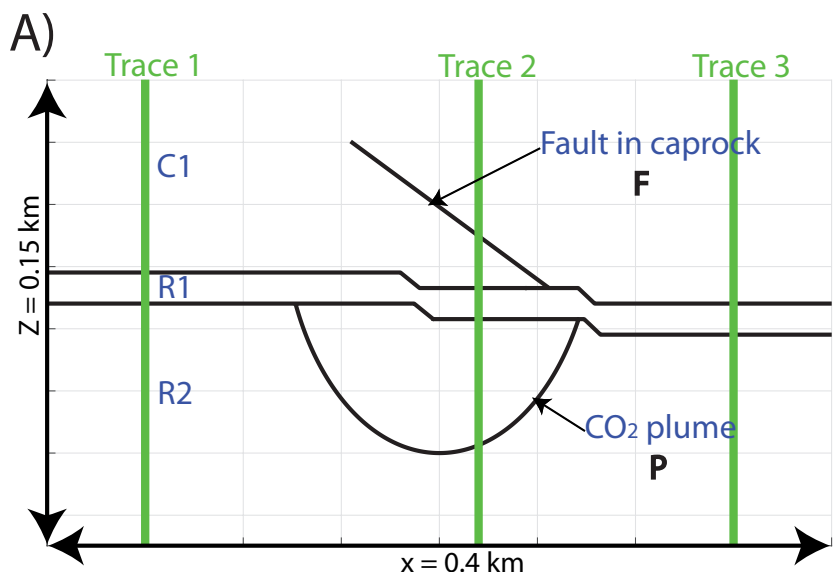

C) Trace 2

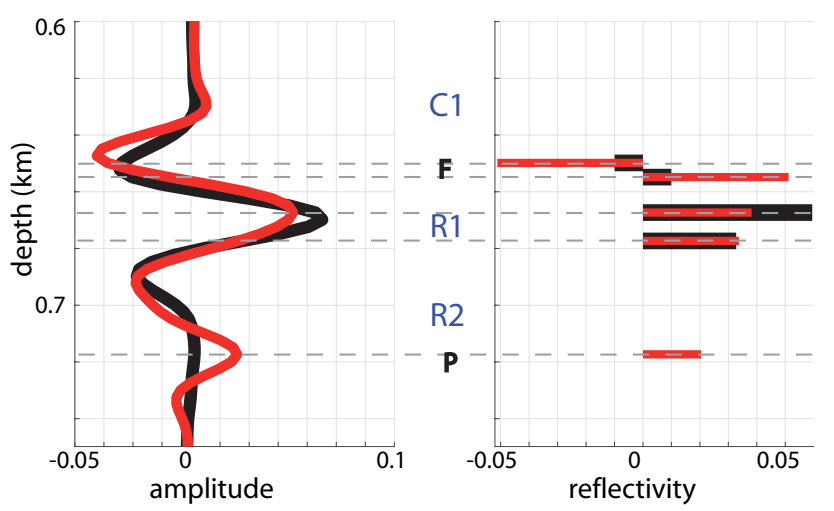

B) Trace 1
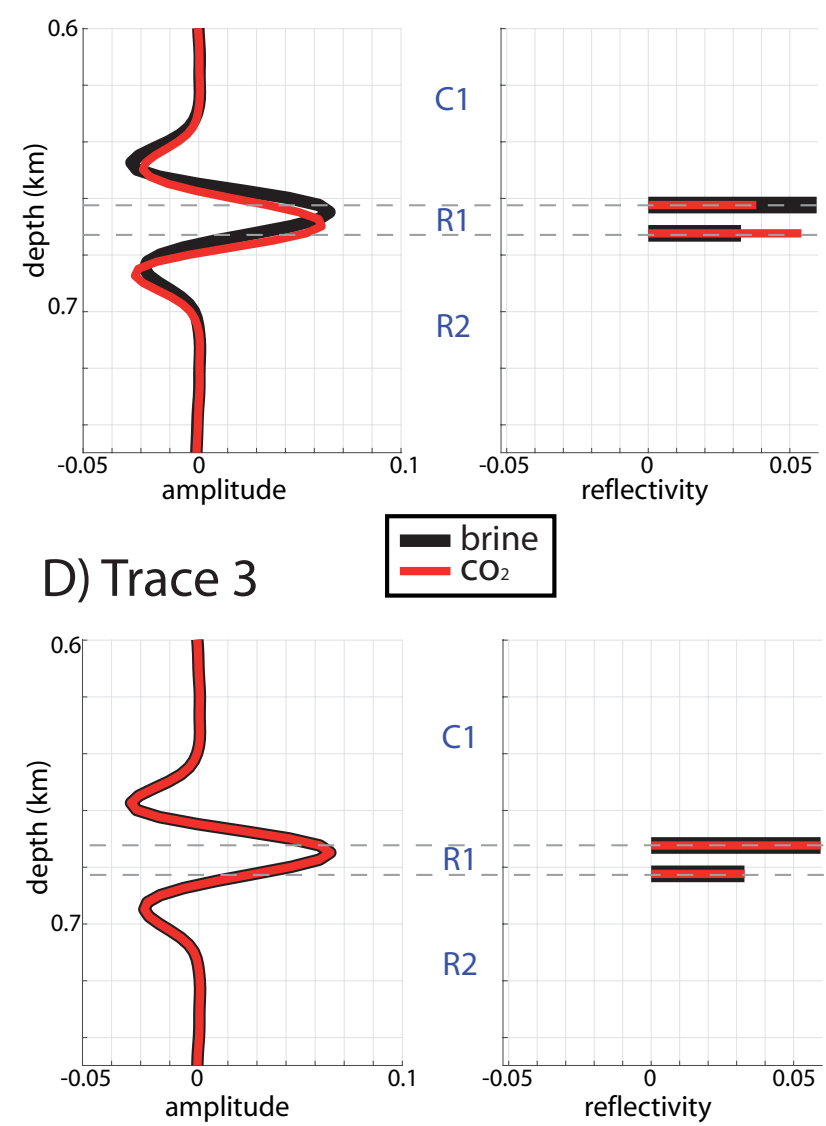

Figure 11. (A) Locations at which seismic traces are extracted from the PSDM seismic image (C1 - caprock, R1 - upper part of the reservoir, R2 - rest of the reservoir). (B) to (D): seismic traces and reflectivity diagrams. (B) Trace cutting through caprock saturated with brine, $R 1$ saturated with $\mathrm{CO}_{2}$ and $\mathrm{R} 2$ saturated with brine. (C) Trace intersecting the caprock and the fault within $\mathrm{C1}$ saturated with brine, R1 as well as R2, both saturated with $\mathrm{CO}_{2}$. (D) Trace crossing $\mathrm{C1}, \mathrm{R} 1$ and $\mathrm{R} 2$ at a location where they are saturated with brine. Black traces are extracted from the model filled with brine (model S1) and red traces are extracted from the model in which the Wilhelmøya subgroup, the De Geerdalen Formation and the fault are filled with $\mathrm{CO}_{2}$ (model S6).

its spatial pattern is filtered in the same manner as the seismic signals during migration, hence being similarly smeared and distorted. The noise amplitude is calibrated to $33 \%$ of the maximum seismic amplitude (hence a signal-to-noise ratio of 3 ), thus corresponding to an average variation of the difference in seismic amplitudes for PSDM sections with or excluding $\mathrm{CO}_{2}$. Fig. $12 \mathrm{C}$, D presents the PSDM sections for a pristine reservoir and a reservoir with $\mathrm{CO}_{2}$ injected in parts. Fig. 12E, F displays the same sections with the noise superimposed.

Although the caprock fault is only defined by a porosity change, it is visible caprock fault in both cases, with and without superimposed noise (Fig. 12D, F). In addition, the contact between caprock and reservoir is highlighted slightly if $\mathrm{CO}_{2}$ is present, such that its lateral distribution in the reservoir could potentially be constrained, especially in a $4 \mathrm{D}$-mode, i.e., in comparison between a base (before $\mathrm{CO}_{2}$ injection) and monitor survey (during $\mathrm{CO}_{2}$ injection).

\section{Discussion}

\section{Outcrop to seismic}

In this study, we have defined a structural model on the basis of a $3 \mathrm{D}$ virtual outcrop constructed using photogrammetric processing. This is complementary to traditional field campaigns conducted on the outcropping reservoir previously (e.g., Ogata et al., 2014b; Mulrooney et al., 2019; Rismyhr et al., 2019), and provides quantitative datasets directly applicable in reservoir model building. The acquisition and processing cost was minimal in contrast to laser scanning, and the quality deemed very high given the study's purpose. Such virtual outcrop models can be constructed at a range of scales, and the vegetation-free exposures on Svalbard are particularly suitable for large, seismic-scale, outcrop studies (Anell et al., 2016). Detailed outcrop-scale work is also possible, and a range of manual and semi-automatic workflows exist for both fracture and sedimentological 
A) acoustic impedance for P-wave

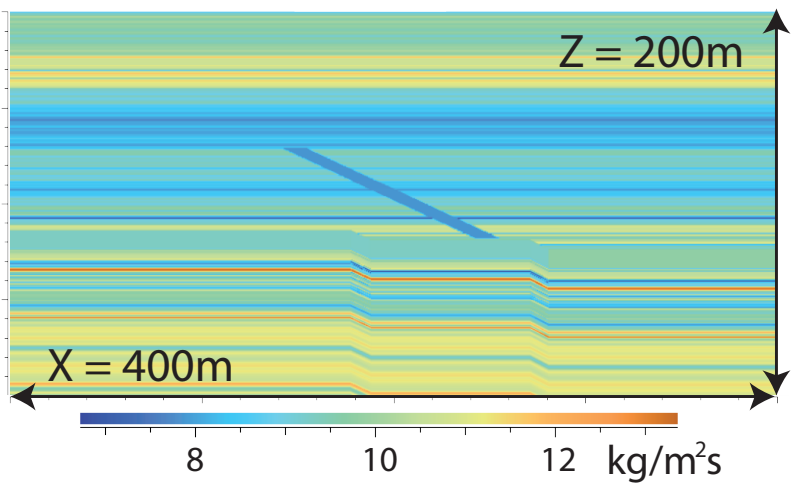

C) model L1

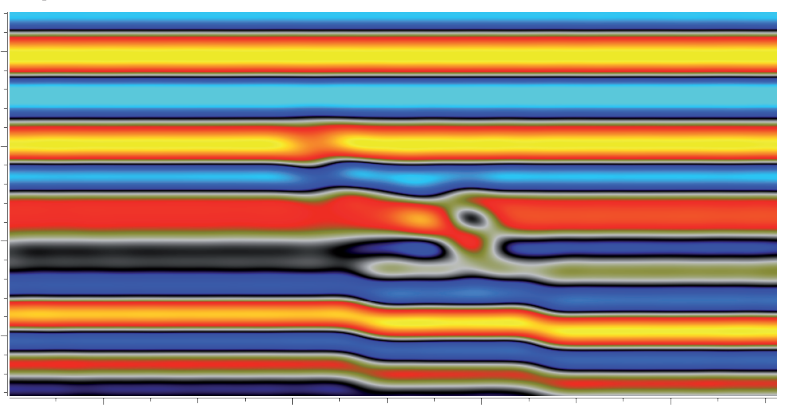

0.1

\section{amplitude}

F) model L2n

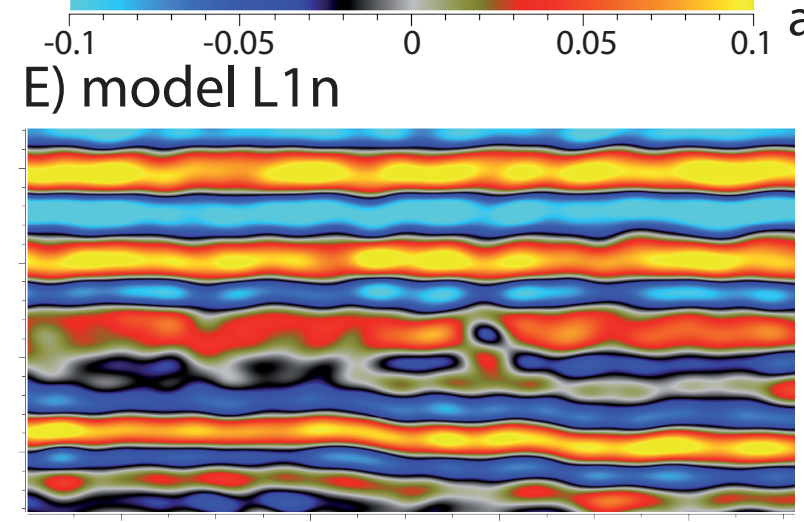

B) matrix of $33 \%$ random noise

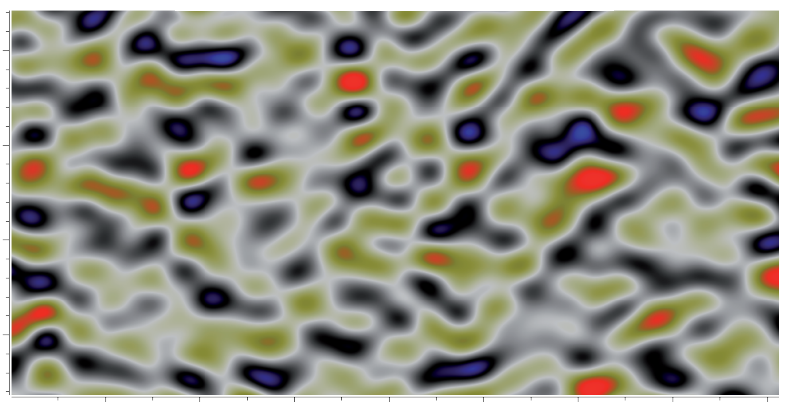

D) model L2

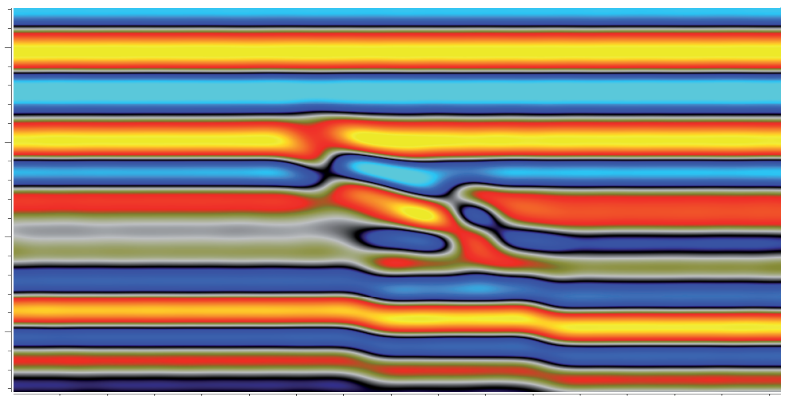

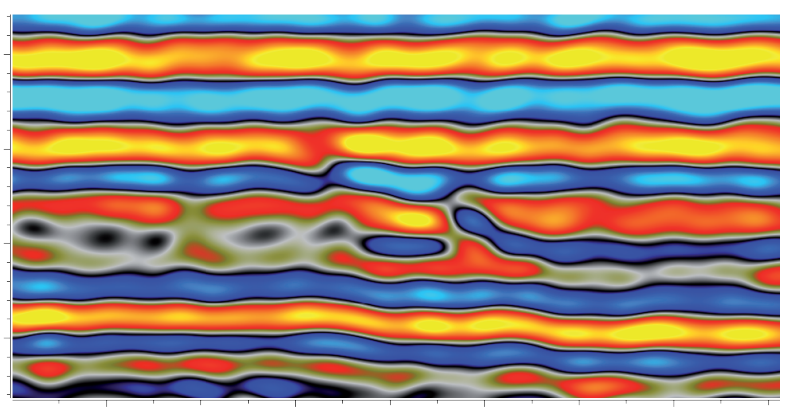

Figure 12. (A) P-wave impedance for layered model characterised by thin layers displayed in Fig. 7C. (B) 33\% random seismic-coloured noise. (C) PSDM seismic section for pristine reservoir. (D) Wilhelmøya reservoir as well as fault fully saturated with $C_{2}$. (E) Same PSDM sections as in (C), but superimposed with noise. (F) Same PSDM sections as in (D), but superimposed with noise. Refer to Table 1 for details on models L1-L2(n).

characterisation of virtual outcrops (Hodgetts, 2013; Casini et al., 2016; Cawood et al., 2017).

In the present work, the virtual outcrop model is used to bridge the gap to conventional seismic data through seismic modelling of relatively small-scale geological features. We have set out to address geological scenarios including "How will the seismic signature change if $\mathrm{CO}_{2}$ starts propagating along a fault zone?", something that is readily addressed using the workflow presented herein, and discussed below. The workflow, however, also represents an important framework for future studies dedicated to seismic imaging of outcrops and thus aiding interpretation of seismic data.
Seismic detection of $\mathrm{CO}_{2}$

Previous research has demonstrated the detectability of relatively large $\mathrm{CO}_{2}$ plumes by active seismic measurements, where the focus so far has been on addressing high-porosity aquifers with a large contribution of the fluid component to the overall elastic properties. Chadwick et al. (2010), for instance, presented a quantitative analysis of the Sleipner industrial-scale $\mathrm{CO}_{2}$ storage site in the northern North Sea. This study illustrates the potential for seismic imaging of both the lateral extent of the plume and the vertical subdivision of the $\mathrm{CO}_{2}$ by intra-formational shale layers. The authors point to a number of challenges including time-lapse reflectivity fading and seismic imaging issues related to 
a generally increasing $\mathrm{CO}_{2}$ saturation within the plume envelope (Chadwick et al., 2010).

On a smaller scale, Daley et al. (2008) presented timelapse vertical seismic profiling and cross-well seismic data utilised to image a pilot-scale $\mathrm{CO}_{2}$ injection campaign of 1600 tons of $\mathrm{CO}_{2}$ into the Frio Formation located in Texas at a depth of $1500 \mathrm{~m}$. Both P- and S-waves were recorded and $\mathrm{CO}_{2}$ saturations were calculated on the basis of a rock physics model calibrated by the observed change in P-wave velocity of up to $500 \mathrm{~m} / \mathrm{s}$. The results are significant as they illustrate the detectability of $\mathrm{CO}_{2}$ migration away from large-scale plumes and are similar in scale to future pilot-scale injections envisioned for the Longyearbyen case study.

The Ketzin site in Germany represents a pilot-scale scientific $\mathrm{CO}_{2}$ injection campaign where 67,000 tons of $\mathrm{CO}_{2}$ were injected over a 5-year period (Ivandic et al., 2015), equivalent to one year of emissions from Longyearbyen's power plant. Förster et al. (2006) provided a comprehensive baseline characterisation of the site, while subsequent works document geophysical monitoring by time-lapse 3D seismic (Ivandic et al., 2015), cross-well seismic (Zhang et al., 2012), surfacedownhole time-lapse electrical resistivity tomography (Bergmann et al., 2012) reactivity experiments on reservoir sandstones (Fischer et al., 2013) and numerical simulations of $\mathrm{CO}_{2}$ migration (Kempka \& Kühn, 2013). Such an integrated and multi-disciplinary approach is required especially when small quantities of $\mathrm{CO}_{2}$ are involved as in the presented Longyearbyen $\mathrm{CO}_{2}$ lab case, or where focus is on monitoring potential $\mathrm{CO}_{2}$ leakage.

Onshore Svalbard, seismic imaging is further complicated by the presence of permafrost. Permafrost typically exhibits higher seismic velocities than unfrozen ground. In the study area, it is approximately $120 \mathrm{~m}$ thick. The spatial and temporal variation in both permafrost thickness and ice content needs to be considered when processing and interpreting seismic profiles (Johansen et al., 2003). Cross-well time-lapse seismic, as discussed by Daley et al. (2008), may therefore represent a viable alternative for seismic monitoring of pilot-scale $\mathrm{CO}_{2}$ plumes in areas where permafrost is present.

\section{Detecting $\mathrm{CO}_{2}$ migration pathways}

For large-scale $\mathrm{CO}_{2}$ storage to be viable, operators need to provide regulators with evidence that injected $\mathrm{CO}_{2}$ remains underground in order to obtain a storage permit. Geophysical monitoring techniques, including seismic, EM, gravimetry and remote sensing can all be used in this context (e.g., Chadwick et al., 2009; Bergmann et al., 2016 and references therein). The spatial extent of a plume envelope is often relatively well constrained, but hypothetical migration and detection thresholds are poorly constrained when $\mathrm{CO}_{2}$ exploits pre-existing zones of weakness, such as fault planes. Our current understanding of $\mathrm{CO}_{2}$ leakage along such features is partly based on studying natural analogues of $\mathrm{CO}_{2}$ leakage, such as the zones bleached by past fluid migration in SE Utah (Shipton et al., 2004; Ogata et al., 2014a). However, uncertainty remains as to how such along-fault $\mathrm{CO}_{2}$ migration can be geophysically imaged.

To address this knowledge gap, we constructed a model with a hypothetical fault extending from the $\mathrm{CO}_{2}$ saturated reservoir into the caprock. The fault's geometry is based on the orientation of faults exposed at nearby outcrops, and the fault is progressively filled with $\mathrm{CO}_{2}$. The fault is first modelled as a zone of enhanced porosity within the homogeneous caprock, and as such is also visible without the presence of $\mathrm{CO}_{2}$. The migration of $\mathrm{CO}_{2}$ along this fault, however, greatly enhances its reflectivity due to the contrast with the surrounding brine-saturated caprock, even when a more complex background velocity model and more realistic survey parameters are employed or noise is added to the seismic traces. This result provides hope that $\mathrm{CO}_{2}$ escaping from a reservoir by means of preexisting weakness zones can be monitored by repeated seismic surveys. We advocate that such seismic surveys are performed as 3D surveys, since this leads both to higher repeatability (Pevzner et al., 2011) and to smaller artefacts (Lubrano-Lavadera et al., 2018).

Since we are primarily interested in monitoring the extent of the $\mathrm{CO}_{2}$ plume along the fault zone, we employed an end-member case of a $\mathrm{CO}_{2}$-saturated fault zone. Clearly, $\mathrm{CO}_{2}$ saturation is likely to vary significantly with respect to physical reservoir properties (e.g., temperature, pressure, porosity, permeability), wettability, relative permeability and time since injection. Chemical fluidrock interactions are often more significant with $\mathrm{CO}_{2}{ }^{-}$ rich fluids than with hydrocarbons and are particularly important in the caprock (e.g., Alemu et al., 2011). These reactions may enhance permeability through dissolution, but may also contribute to sealing of pathways through the precipitation of carbonate minerals.

\section{Conclusions}

Through an integrated workflow focusing on generating synthetic seismic models of a reservoir-caprock interface characterised using virtual outcrop models on Svalbard we conclude that:

- The photogrammetric analysis provides a cost-efficient means to develop accurate virtual models of the outcrops in the Konusdalen region suitable for defining the geometry required for seismic forward modelling.

- Small-scale (i.e., few metres displacement) normal faults as seen at Konusdalen and most likely 
compartmentalise the reservoir at the proposed storage site in Adventdalen are unlikely to be imaged using active seismic data due to resolution limits.

- With the selected acquisition parameters, it is not possible to discriminate the top of the Wilhelmøya Subgroup reservoir and its base given the low reservoir thickness.

- End-member cases representing $\mathrm{CO}_{2}$ saturation illustrate that even in relatively tight reservoirs, there is potential for detecting $\mathrm{CO}_{2}$ plumes.

- Seismic imaging of $\mathrm{CO}_{2}$ migrating along a hypothetical fault zone in the caprock appears feasible, though large uncertainties exist on the petrophysical characteristics of fault zones in shale-dominated successions.

- We compare geologically simple with more complex models, as well as noise-less and noisy models, to illustrate the imaging degradation with increasing complexity.

- Comparison of outcrop observations with real-world 2D seismic data illustrates the limitations of seismic data with respect to both vertical and horizontal resolution, and the need for optimal use of outcrop analogue data in seismic data interpretation. Forward seismic modelling, as presented in this contribution, provides the necessary bridge between the different data types and disciplines.

Acknowledgements. This research has been funded by FME-SUCCESS supported by academic and industrial partners and the Research Council of Norway (grant number 193825) and hosted by the Christian Michelsen Institute. We sincerely appreciate data access provided by the Longyearbyen $\mathrm{CO}_{2}$ lab project (http://co2-ccs.unis.no). The authors thank NORSAR, Schlumberger and Cegal for academic use of the SeisRoX seismic modelling software, Petrel and the Blueback Toolbox, respectively. Simon Buckley at the Centre for Integrated Petroleum Research (part of NORCE) in Bergen provided access to the Lime $3 \mathrm{D}$ virtual outcrop interpretation package. We appreciate technical discussions with our research partners and colleagues, notably Snorre Olaussen, Alvar Braathen, Kei Ogata, Tor Arne Johansen and Bent Ole Ruud, and the field assistance of Tom Birchall and Peter Betlem. We are grateful to the insightful comments provided by the reviewers Ingrid Anell and Christopher Juhlin, and the editorial handling by Trond Slagstad. This is a contribution of the NCCS (RCN\# 257579).

\section{References}

Alemu, B.L., Aagaard, P., Munz, I.A. \& Skurtveit, E. 2011: Caprock interaction with $\mathrm{CO}_{2}$ : A laboratory study of reactivity of shale with supercritical $\mathrm{CO}_{2}$ and brine. Applied Geochemistry 26, 1975-1989. https://doi.org/10.1016/j.apgeochem.2011.06.028.

Anell, I., Braathen, A. \& Olaussen, S. 2014: The Triassic-Early Jurassic of the northern Barents Shelf: a regional understanding of the Longyearbyen $\mathrm{CO}_{2}$ reservoir. Norwegian Journal of Geology 94, 83-98.

Anell, I., Lecomte, I., Braathen, A. \& Buckley, S. 2016: Synthetic seismic illumination of small-scale growth faults, paralic deposits and low-angle clinoforms: A case study of the Triassic successions on Edgeøya, NW Barents Shelf. Marine and Petroleum Geology 77, 625-639. https://doi.org/10.1016/j.marpetgeo.2016.07.005.

Bachu, S. 2008: $\mathrm{CO}_{2}$ storage in geological media: Role, means, status and barriers to deployment. Progress in Energy and Combustion Science 34, 254-273. https://doi.org/10.1016/j.pecs.2007.10.001.

Beka, T.I., Senger, K., Autio, U.A., Smirnov, M. \& Birkelund, Y. 2017: Integrated electromagnetic data investigation of a Mesozoic $\mathrm{CO}_{2}$ storage target reservoir-cap-rock succession, Svalbard. Journal of Applied Geophysics 136, 417-430.

https://doi.org/10.1016/j.jappgeo.2016.11.021.

Bergmann, P., Schmidt-Hattenberger, C., Kiessling, D., Rücker, C., Labitzke, T., Henninges, J., Baumann, G. \& Schütt, H. 2012: Surfacedownhole electrical resistivity tomography applied to monitoring of $\mathrm{CO}_{2}$ storage at Ketzin, Germany. GEOPHYSICS 77, B253-B267. https://doi.org/10.1190/geo2011-0515.1.

Bergmann, P., Diersch, M., Götz, J., Ivandic, M., Ivanova, A., Juhlin, C., Kummerow, J., Liebscher, A., Lüth, S. \& Meekes, S. 2016: Review on geophysical monitoring of $\mathrm{CO}_{2}$ injection at Ketzin, Germany. Journal of Petroleum Science and Engineering 139, 112-136. https://doi.org/10.1016/j.petrol.2015.12.007.

Blinova, M., Faleide, J.I., Gabrielsen, R.H. \& Mjelde, R. 2013: Analysis of structural trends of sub-sea-floor strata in the Isfjorden area of the West Spitsbergen Fold-and-Thrust Belt based on multichannel seismic data. Journal of the Geological Society 170, 657-668. https://doi.org/10.1144/jgs2012-109.

Braathen, A., Bælum, K., Christiansen, H.H., Dahl, T., Eiken, O., Elvebakk, H., Hansen, F., Hanssen, T.H., Jochmann, M., Johansen, T.A., Johnsen, H., Larsen, L., Lie, T., Mertes, J., Mørk, A., Mørk, M.B., Nemec, W., Olaussen, S., Oye, V., Rød, K., Titlestad, G.O., Tveranger, J. \& Vagle, K. 2012: The Longyearbyen $\mathrm{CO}_{2}$ Lab of Svalbard, Norway-initial assessment of the geological conditions for $\mathrm{CO}_{2}$ sequestration. Norwegian Journal of Geology 92, 353-376

Buckley, S.J., Howell, J.A., Enge, H.D. \& Kurz, T.H. 2008: Terrestrial laser scanning in geology: data acquisition, processing and accuracy considerations. Journal of the Geological Society 92, 165, 625-638. https://doi.org/10.1144/0016-76492007-100.

Bælum, K. \& Braathen, A. 2012: Along-strike changes in fault array and rift basin geometry of the Carboniferous Billefjorden Trough, Svalbard, Norway. Tectonophysics 546-547, 38-55. https://doi.org/10.1016/j.tecto.2012.04.009.

Bælum, K., Johansen, T.A., Johnsen, H., Rød, K., Ruud, B.O. \& Braathen, A. 2012: Subsurface geometries of the Longyearbyen $\mathrm{CO}_{2}$ lab in Central Spitsbergen, as mapped by reflection seismic data. Norwegian Journal of Geology 92, 377-389.

Casini, G., Hunt, D., Monsen, E. \& Bounaim, A. 2016: Fracture characterization and modeling from virtual outcrops. American Association of Petroleum Geologists Bulletin 100, 41-61. https://doi.org/10.1306/09141514228.

Cawood, A.J., Bond, C.E., Howell, J.A., Butler, R.W.H. \& Totake, Y. 2017: LiDAR, UAV or compass-clinometer? Accuracy, coverage and the effects on structural models. Journal of Structural Geology 98, 67-82. https://doi.org/10.1016/j.jsg.2017.04.004. 
Chadwick, R.A., Arts, R., Bentham, M., Eiken, O., Holloway, S., Kirby, G.A., Pearce, J.M., Williamson, J.P. \& Zweigel, P. 2009: Review of monitoring issues and technologies associated with the long-term underground storage of carbon dioxide. In Evans, D.J. \& Chadwick, R.A. (eds.): Underground Gas Storage: Worldwide Experiences and Future Development in the UK and Europe. Geological Society of London Special Publications 313, pp. 257-275.

https://doi.org/10.1144/SP313.15.

Chadwick, A., Williams, G., Delepine, N., Clochard, V., Labat, K., Sturton, S., Buddensiek, M.-L., Dillen, M., Nickel, M. \& Lima, A.L. 2010: Quantitative analysis of time-lapse seismic monitoring data at the Sleipner $\mathrm{CO}_{2}$ storage operation. The Leading Edge 29, 170177. https://doi.org/10.1190/1.3304820.

Daley, T., Myer, L., Peterson, J., Majer, E. \& Hoversten, G. 2008: Timelapse crosswell seismic and VSP monitoring of injected $\mathrm{CO}_{2}$ in a brine aquifer. Environmental Geology 54, 1657-1665. https://doi.org/10.1007/s00254-007-0943-z.

Dallmann, W. 2015: Geoscience Atlas of Svalbard. Norsk Polarinstitutt Rapportserie 148, 292 pp.

Doughty, C., Freifeld, B. \& Trautz, R. 2008: Site characterization for $\mathrm{CO}_{2}$ geologic storage and vice versa: the Frio brine pilot, Texas, USA as a case study. Environmental Geology 54, 1635-1656. https://doi.org/10.1007/s00254-007-0942-0.

Eiken, O., Ringrose, P., Hermanrud, C., Nazarian, B., Torp, T.A. \& Høier, L. 2011: Lessons learned from 14 years of CCS operations: Sleipner, In Salah and Snøhvit. Energy Procedia 4, 5541-5548. https://doi.org/10.1016/j.egypro.2011.02.541.

Elvebakk, H. 2010: Results of borehole logging in well LYB $\mathrm{CO}_{2}, \mathrm{Dh} 4$ of 2009, Longyearbyen, Svalbard. NGU Report 2010.018, 35 pp.

Fischer, S., Liebscher, A., De Lucia, M. \& Hecht, L. 2013: Reactivity of sandstone and siltstone samples from the Ketzin pilot $\mathrm{CO}_{2}$ storage site-Laboratory experiments and reactive geochemical modeling. Environmental Earth Sciences 70, 3687-3708. https://doi.org/10.1007/s12665-013-2669-4.

Förster, A., Norden, B., Zinck-Jørgensen, K., Frykman, P., Kulenkampff, J., Spangenberg, E., Erzinger, J., Zimmer, M., Kopp, J., Borm, G., Juhlin, C., Cosma, C.-G. \& Hurter, S. 2006: Baseline characterization of the $\mathrm{CO}_{2}$ SINK geological storage site at Ketzin, Germany. Environmental Geosciences 13, 145-161. https://doi.org/10.1306/eg.02080605016.

Gassmann, F. 1951: Elastic waves through a packing of spheres. Geophysics 16, 673-685. https://doi.org/10.1190/1.1437718.

Gozalpour, F., Ren, S. \& Tohidi, B. 2005: $\mathrm{CO}_{2}$ EOR and storage in oil reservoir. Oil \& gas science and technology 60, 537-546. https://doi.org/10.2516/ogst:2005036.

Herron, D.A. 2011: First steps in seismic interpretation. Society of Exploration Geophysicists, 216 pp. https://doi.org/10.1190/1.9781560802938.

Hodgetts, D. 2013: Laser scanning and digital outcrop geology in the petroleum industry: a review. Marine and Petroleum Geology 46, 335-354. https://doi.org/10.1016/j.marpetgeo.2013.02.014.

Ivandic, M., Juhlin, C., Lueth, S., Bergmann, P., Kashubin, A., Sopher, D., Ivanova, A., Baumann, G. \& Henninges, J. 2015: Geophysical monitoring at the Ketzin pilot site for $\mathrm{CO}_{2}$ storage: New insights into the plume evolution. International Journal of Greenhouse Gas Control 32, 90-105. https://doi.org/10.1016/j.ijggc.2014.10.015.

Johansen, T.A., Digranes, P., van Schaack, M. \& Lønne, I. 2003: Seismic mapping and modeling of near-surface sediments in polar areas. Geophysics 68, 566-573. https://doi.org/10.1190/1.1567226.

Johansen, T.A., Ruud, B.O., Bakke, N.E., Riste, P., Johannessen, E.P. \& Henningsen, T. 2011: Seismic profiling on Arctic glaciers. First Break 29, 65-71.

Johnsen, Ø. \& Skurtveit, E. 2010: Mechanical testing of material from Dh4, Longyearbyen $\mathrm{CO}_{2}$ Lab. Norwegian Geotechnical Institute Report 200B1351-00-19-R, $36 \mathrm{pp}$.
Kempka, T. \& Kühn, M. 2013: Numerical simulations of $\mathrm{CO}_{2}$ arrival times and reservoir pressure coincide with observations from the Ketzin pilot site, Germany. Environmental Earth Sciences 70, 36753685. https://doi.org/10.1007/s12665-013-2614-6.

Koevoets, M.J., Hammer, Ø., Olaussen, S., Senger, K. \& Smelror, M. 2019: Integrating subsurface and outcrop data of the Middle Jurassic to Lower Cretaceous Agardhfjellet Formation in central Spitsbergen. Norwegian Journal of Geology 99, 213-246. https://dx.doi.org/10.17850/njg98-4-01.

Larsen, L. 2012: Summary of Well Test Results from DH4, DH5, DH6, DH5R and DH7a. Unpublished UNIS CO lab report, $52 \mathrm{pp}$.

Lecomte, I. 2008: Resolution and illumination analyses in PSDM: A ray-based approach. The Leading Edge 27, 650-663. https://doi.org/10.1190/1.2919584.

Lecomte, I., Lubrano-Lavadera, P., Anell, I., Buckley, S.J., Schmid, D.W. \& Heeremans, M. 2015: Ray-based seismic modeling of geologic models: Understanding and analyzing seismic images efficiently. Interpretation 3, SAC71-SAC89. https://doi.org/10.1190/INT-2015-0061.1.

Lecomte, I., Lubrano-Lavadera, P.L., Botter, C., Anell, I., Buckley, S.J., Eide, C.H., Grippa, A., Mascolo, V. \& Kjoberg, S. 2016: 2 (3) D convolution modelling of complex geological targets beyond-1D convolution. First Break 34, 99-107.

Lubrano-Lavadera, P., Kühn, D., Dando, B., Lecomte, I., Senger, K. \& Drottning, A. 2018: CO2 storage in the high Arctic: efficient modelling of prestack-depth migrated seismic sections for survey planning. Geophysical Prospecting 66, 1180-1200. https://doi.org/10.1111/1365-2478.12637.

Michael, K., Golab, A., Shulakova, V., Ennis-King, J., Allinson, G., Sharma, S. \& Aiken, T. 2010: Geological storage of $\mathrm{CO}_{2}$ in saline aquifers-A review of the experience from existing storage operations. International Journal of Greenhouse Gas Control 4, 659667. https://doi.org/10.1016/j.ijggc.2009.12.011.

Mulrooney, M.J., Larsen, L., Rismyhr, B., Van Stappen, J., Senger, K., Braathen, A., Mørk, M.B., Olaussen, S., Cnudde, V. \& Ogata K. 2019: Fluid flow properties of a potential unconventional $\mathrm{CO}_{2}$ storage unit in central Spitsbergen: the Upper Triassic to Middle Jurassic Wilhelmøya Subgroup. Norwegian Journal of Geology 99 279-310. https://doi.org/10.17850/njg002.

Mørk, M.B.E. 2013: Diagenesis and quartz cement distribution of lowpermeability Upper Triassic -Middle Jurassic reservoir sandstones, Longyearbyen $\mathrm{CO}_{2}$ lab well site in Svalbard, Norway. American Association of Petroleum Geologists Bulletin 97, 577-596. https://doi.org/10.1306/10031211193.

Nøttvedt, A., Livbjerg, F., Midbøe, P.S. \& Rasmussen, E. 1993: Hydrocarbon potential of the Central Spitsbergen Basin. In Vorren, T.O. \& Bergsager, E. (eds.): Arctic Geology and Petroleum Potential, Elsevier Special Publications, pp. 333-361. https://doi.org/10.1016/B978-0-444-88943-0.50026-5.

Ogata, K., Senger, K., Braathen, A., Tveranger, J. \& Olaussen, S. 2012: The importance of natural fractures in a tight reservoir for potential $\mathrm{CO}_{2}$ storage: case study of the upper Triassic to middle Jurassic Kapp Toscana Group (Spitsbergen, Arctic Norway). In Spence, G.H., Redfern, J., Aguilera, R., Bevan, T.G., Cosgrove, J.W., Couples, G.D. \& Daniel, J.-M. (eds.): Advances in the Study of Fractured Reservoirs London, Geological Society of London Special Publications 374, pp. 395-415.

Ogata, K., Senger, K., Braathen, A. \& Tveranger, J. 2014a: Fracture corridors as seal-bypass systems in siliciclastic reservoir-cap rock successions: Field-based insights from the Jurassic Entrada Formation (SE Utah, USA). Journal of Structural Geology 66, 162187. https://doi.org/10.1016/j.jsg.2014.05.005.

Ogata, K., Senger, K., Braathen, A., Tveranger, J. \& Olaussen, S. 2014b: Fracture systems and meso-scale structural patterns in the siliciclastic Mesozoic reservoir-caprock succession of the Longyearbyen $\mathrm{CO}_{2} \mathrm{Lab}$ project: implications for geologic $\mathrm{CO}_{2}$ sequestration on Central Spitsbergen, Svalbard. Norwegian Journal of Geology 94, 121-154. 
Ogaya, X., Ledo, J., Queralt, P., Marcuello, Á. \& Quintà, A. 2013: First geoelectrical image of the subsurface of the Hontomín site (Spain) for $\mathrm{CO}_{2}$ geological storage: a magnetotelluric $2 \mathrm{D}$ characterization. International Journal of Greenhouse Gas Control 13, 168-179. https://doi.org/10.1016/j.ijggc.2012.12.023.

Pevzner, R., Shukalova, V., Kepic, A. \& Urosevic, M. 2011: Repeatability analysis of land time-lapse seismic data: $\mathrm{CO}_{2} \mathrm{CRC}$ Otway pilot project case study. Geophysical Prospecting 59, 66-77. https://doi.org/10.1111/j.1365-2478.2010.00907.x.

Ringrose, P., Thorsen, R., Zweigel, P., Nazarian, B., Furre, A.-K., Paasch, B., Thompson, N. \& Karstad, P. 2017: Ranking and Risking Alternative $\mathrm{CO}_{2}$ Storage Sites Offshore Norway. Fourth Sustainable Earth Sciences Conference 3-7 September, Malmö, Sweden.

Rismyhr, B., Bjærke, T., Olaussen, S., Mulrooney, M.J. \& Senger K. 2019: Facies, palynostratigraphy and sequence stratigraphy of the Wilhelmøya Subgroup (Upper Triassic-Middle Jurassic) in western central Spitsbergen, Svalbard. Norwegian Journal of Geology 99, 183-212. https://doi.org/10.17850/njg001.

Roy, S., Senger, K., Noormets, R., Braathen, A. \& Olaussen, S. 2014: Fluid migration pathways to seafloor fluid seepage in inner Isfjorden and Adventfjorden, Svalbard. Norwegian Journal of Geology 94, 99-119.

Senger, K., Roy, S., Braathen, A., Buckley, S.J., Bælum, K., Gernigon, L., Mjelde, R., Noormets, R., Ogata, K., Olaussen, S., Planke, S., Ruud, B.O. \& Tveranger, J. 2013: Geometries of doleritic intrusions in central Spitsbergen, Svalbard: an integrated study of an onshore-offshore magmatic province with implications on $\mathrm{CO}_{2}$ sequestration. Norwegian Journal of Geology 93, 143-166.

Senger, K., Tveranger, J., Braathen, A., Olaussen, S., Ogata, K. \& Larsen, L. 2015: $\mathrm{CO}_{2}$ storage resource estimates in unconventional reservoirs: insights from a pilot-sized storage site in Svalbard, Arctic Norway. Environmental Earth Sciences 73, 3987-4009. https://doi.org/10.1007/s12665-014-3684-9.

Shipton, Z.K., Evans, J.P., Kirschner, D., Kolesar, P.T., Williams, A.P. \& Heath, J. 2004: Analysis of $\mathrm{CO}_{2}$ leakage through 'low-permeability' faults from natural reservoirs in the Colorado Plateau, east-central Utah. In Baines, S.J. \& Worden, R.H. (eds.): Geological Storage of Carbon Dioxide, Geological Society of London Special Publication, 43-58.

Span, R. \& Wagner, W. 1996: A New Equation of State for Carbon Dioxide Covering the Fluid Region from the Triple-Point Temperature to $100 \mathrm{~K}$ at Pressures up to $800 \mathrm{MPa}$. Journal of Physical Chemical Reference Data 25, 1509-1596. https://doi.org/10.1063/1.555991.

Tsuji, T., Ikeda, T., Johansen, T.A. \& Ruud, B.O. 2016: Using seismic noise derived from fluid injection well for continuous reservoir monitoring. Interpretation 4, SQ1-SQ11. https://doi.org/10.1190/INT-2016-0019.1.

UNIS $\mathrm{CO}_{2}$ lab AS 2015: Longyearbyen $\mathrm{CO}_{2}$ lab - Phase II Final Report, available at http://co2-ccs.unis.no/Pdf/Longyearbyen $\% 20 \mathrm{CO} \% 20$ lab\%20Phase\%202\%20Report_10_2015.pdf, 44 pp.

Vilamajó, E., Queralt, P., Ledo, J. \& Marcuello, A. 2013: Feasibility of Monitoring the Hontomín (Burgos, Spain) $\mathrm{CO}_{2}$ Storage Site Using a Deep EM Source. Surveys in Geophysics 34, 441-461. https://doi.org/10.1007/s10712-013-9238-y.

Westoby, M., Brasington, J., Glasser, N., Hambrey, M. \& Reynolds, J. 2012: 'Structure-from-Motion'photogrammetry: A low-cost, effective tool for geoscience applications. Geomorphology 179, 300314.

https://doi.org/10.1016/j.geomorph.2012.08.021.

Zhang, F., Juhlin, C., Cosma, C., Tryggvason, A. \& Pratt, R.G. 2012: Cross-well seismic waveform tomography for monitoring $\mathrm{CO}_{2}$ injection: a case study from the Ketzin Site, Germany. Geophysical Journal International 189, 629-646.

https://doi.org/10.1111/j.1365-246X.2012.05375.x. 
